\title{
A proteção do consumidor de produtos e serviços estrangeiros no Brasil: primeiras observações sobre os contratos à distância no comércio eletrônico' ${ }^{1}$
}

\author{
Dra. Claudia Lima Marques
}

Professora da Faculdade de Direito da Universidade Federal do Rio Grande do Sul, Porto Alegre, Brasil, Doutora em Direito pela Universidade de Heidelberg, Alemanha, Mestre em Direito Civil e Direito Internacional Privado pela Universidade de Tübingen, Alemanha, Especialista em Integração Européia pela Universidade de Saarbrücken, Alemanha, Diretora do Instituto Brasileiro de Política e Défesa do Consumidor, BRASILCON

\section{Introdução}

As relações privadas de consumo assumem hoje também um caráter internacional. Em um mundo de crescentes áreas de complexidade, rapidez e globalização, ${ }^{2}$ há um crescimento na importância do Direito

Internacional Privado ou dos conflitos de leis no espaço também em relação aos atores leigos deste mercado internacional, ${ }^{3}$ cuja porta de entrada pode ser o simples computador (Televisão, Fax, a tela do Palmtop ou mesmo do telefone celular). ${ }^{4}$

1 Este artigo traz extratos da $4^{\text {a }}$ edição de meu livro, "Contratos no Código de Defesa do Consumidor", RT, 2002, no prelo, motivo pelo qual reproduz partes de artigos já publicados, assim como parte da tradução para o português do texto
apresentado na 8 th International Consumer Law Conference -International Association of Consumer Law, 9 a 11 abril, 2001, em Auckland, Nova Zelândia. A autora gostaria de agradecer ao acadêmico Rafael B. Garcia pela primeira tradução de meu texto em inglês, ao Prof. Antonio Herman Benjamin (Univ. de Texas, Austin), ao magistrado Luis Salomão (Juizado Especial do Rio de Janeiro) e ao Doutorando CAPES Fábio Costa Morosini (LL.M., UT-Austin) por materiais e comentários.

2 Aceitarei aqui a definicão de globalizacão feita por CASTELLS, Manuel, End of Millennium (The Information Age:

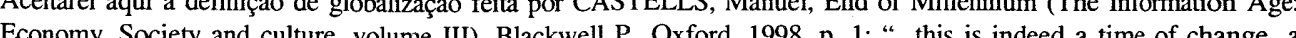
technological revolution centered around information has transformed the way we think, we produce, we consume we trade, we manage we communicate, we live, we die, we make war, and we make love. A dynamic global economy has been constituted around the planet line, we de, we meople and activities from all over world, while switching off from the networks of power and wealth, people and territories dubbed as irrelevant from the perspective of dominant interests..."

3 Veja meu artigo, "A insuficiente proteção do consumidor nas normas de Direito Internacional Privado - Da necessidade de uma Convencão Intermmericana (CIDP) sobre a lei aplić́vel a alguns contratos e relacões de consumo", in Revista dos Tribunais, São Paulo, junho de 2001, vol. 788, ano 90, p. 11 a 56 .

4 Veja também a juíza brasileira Fernanda Moron (A Internet e o Direito, Revista Consulex, março 1997, p. 64): "Como se vê, na medida que as relacõos que surgem pela Internet transcendem fronteiras, maior necessidade teremos de recorrer a regras do Direito Internacional, ramo jurídico que com certeza apresentará sensível crescimento"

Revista da Faculdade de Direito da UFRGS, v. 21, Março/2002 
A proteção deste consumidor de produtos e serviços estrangeiros no Brasil interessa ao Direito do Consumidor. ${ }^{5}$ Mister relembrar aqui a distinção tradicional na Alemanha entre consumidor-ativo (aktive Verbraucher), consumidor que se desloca de um país para outro (por exemplo, turista que compra uma filmadora estrangeira no Exterior)e consumidor-passivo (passive Verbraucher), consumidor que recebe a informação, a oferta $e$ que contrata em seu país, sem deslocamento físico (por exemplo, o consumidor que contrata pela Internet, em sua casa, a compra de uma filmadora diretamente de fornecedor com sede no Exterior). ${ }^{6}$

A proteção do consumidor passivo em uma relação de consumo internacional ou pluriconectada é um interessante desafio do Direito atual, pois envolve preocupações jurídico-políticas de dupla natureza: de um lado, o Direito nacional preocupa-se em manter o nível material de proteção dos consumidores assegurado pela lei nacional de proteção dos consumidores; de outro, com a abertura dos mercados e livre concorrência, a idéia mestra é a da facilitação do comércio internacional, mesmo que de consumo, a inserção positiva do país neste mundo de trocas globais, assim como de preservação da liberdade dos consumidores

de escolher com quem contratar em um mercado globalizado, não havendo muito espaço para intervenções territorialistas e xenófobas. É no diálogo entre a finalidade "tutelar do sujeito mais fraco" do Direito do Consumidor nacional e finalidade de "Justiça e harmonia internacional" do Direito Internacional Privado que deve ser procurada a resposta para este desafio.?

O resultado deste diálogo das fontes, como ensina Erik Jayme, ${ }^{8}$ não é o simples uso do método conflitual clássico, em que a norma de Direito Internacional Privado presente na Le de Introdução ao Código Civil, datada de 1942 indicaria qual a lei material, qual a lei de proteção do consumidor, se a nacional ou a estrangeira, seria aplicável de forma excludente ao caso concreto, por exemplo, de contratação pela Internet. Diálogo pressupõe não exclusão e sim colaboração e união para um fim comum. Neste sentido, é standard mundial do Direito Internacional Privado que as normas imperativas (as " $z$ wingende Normen" identificadas por Savigny) encontram aplicação direta, ao lado ou mesmo antes da lei indicada aplicável pela norma de conflitos de leis Diálogo pressupõe tolerância, abertura para opiniões e visões plurais do mesmo fenômeno. Neste sentido, apesar de nossa Lei de Introdução ao Código Civil datar de 1942 e o

s Como afirmamos em nosso primeiro artigo sobre o tema, publicado na RT 788/11 e seg: "Consumir de forma internacional é típico de nossa época. O serviço ou produto estrangeiro é status, é bem simbólico na atual cultura de consumo; o turismo, as viagens", a conexão e o "surf" diário na Internet, "o ser consumidor de forma internacional, fazem parte da procura pós-moderna dos prazeres, do lazer individual, da realização dos sonhos e do imaginário, é uma distinção social cada vez mais importante." Veja neste sentido, Featherstone, Mike, Cultura de Consumo e pós-modernismo, Trad. Júlio Assis Simões, Studio Nobel, São Paulo, 1995, p. 31.

6 A distinção entre consumidor-ativo (que se desloca de um país para outro) e consumidor-passivo (que recebe a informação, que contrata em seu país, sem deslocamento físico) é muito utilizada na Alemanha e será aqui seguida para facilitar a exposição. Veja, por todos, usando a expressão JAYME, Erik e KOHLER, Christian, Europäisches Kollisionsrecht 1999- Die Abendstunde der Staatsverträge, in IPRAX 1999, p. 404. Veja sobre a universalidade do fenomeno, Kronke, Herbert, Applicable Law in Torts and Contracts in Cyberspace, in Law International, 1998, p. 82 e seg.

7 Assim ensina JAYME, Erik, Identité culturelle et intégration: Le droit internationale privé postmoderne - in: Recueil des Cours de l' Académie de Droit International de la Haye, 1995,II, pg. 262 e seg. (citado Jayme, Cours)

${ }^{8}$ JAYME, Cours, p. 59 e seg.

Revista da Faculdade de Direito da UFRGS, v. 21, Março/2002 novo Código, recém aprovado em 10 de janeiro de 2002, infelizmente não vir acompanhado de nova lei de Introdução, a verdade é que a doutrina e a jurisprudência brasileira deram nova leitura a estas normas e aceitam o pluralismo de métodos (conflituais e materiais) no Direito Internaciona Privado brasileiro. Assim, conhece o Direito Internacional Privado brasileiro as denominadas "normas de aplicação imediata", espécies das normas imperativas, que perseguindo um resultado material de Justiça do Direito Internacional Privado aplicam-se aos casos pluriconectados de forma "direta" antes mesmo da norma indireta, da norma de conflito que indicaria uma lei para regular materialmente o caso concreto. ${ }^{9}$

Como se observa, a proteção dos mais fracos, dos vulneráveis, através da dogmática atual do Direito Internacional Privado apresenta uma série de facetas, muitas vezes não analisadas pelos comercialistas, acostumados que estão à solução dos conflitos de leis entre iguais, entre comerciantes, no ágil, altamente concorrencial, pleno de oportunidades e riscos, mercado comercial internacional. Se já sugeri a elaboração de uma Convenção Internacional ${ }^{10}$ que positivasse, de forma clara, estas novas teorias e os limites da finalidade de proteção material do consumidor de produtos e serviços estrangeiros, permitam-me agora, analisar como se dá esta proteção no Brasil, no ordenamento jurídico atual e tecer algumas observações que podem ser úteis, caso uma nova Lei de Introdução venha a ser preparada.

Para facilitar o acompanhamento pelos

menos iniciados na pesada terminologia do Direito Internacional Privado, gostaria de limitar a análise e estudar apenas um exemplo prático, qual seja, análise de como se dá a proteção do consumidor que contrata o fornecimento de produtos e serviços estrangeiros através da Internet, em contratação a distância com fornecedor com sede no Exterior. A análise de como se dá a proteção do consumidor do mercado brasileiro, quando há fato do produtos estrangeiro defeituoso ou quando há fato do serviço estrangeiro defeituoso ficará, assim como a visão dos conflitos de jurisdição, para posteriores artigos. A primeira parte seria assim dedicada à análise do regime da contratação de consumo à distância no Brasil com fornecedor com sede no Exterior e, a segunda, à análise do regime em caso de fato do produto ou do serviço ocorrido no mercado brasileiro.

\section{Visão geral da contratação} de consumo à distância no comércio eletrônico no Brasil

Ao elaborar a $4^{a}$ edição de meu livro sobre contratos, percebi que, dentre as técnicas de contratação de massa na sociedade atual ou pós-moderna, as quais dão azo à nova realidade contratual, estão não somente os já analisados contratos de adesão, as condições gerais contratuais e os contratos cativos de longa duração, mas também -e com grande destaquea contratação à distância no crescente comércio eletrônico de consumo. ${ }^{11}$

Assim MARQUES DOS SANTOS, António, As normas de Aplicação imediata no Direito Internacional Privado - Esboço de uma Teoria Geral- vol. I, Coleccão de Teses, Ed. Almedina,Coimbra, 1991, p. 11. Veja também SCHWANDER, Ivo, Lois d'application immédiate, Sonderanknüpfung, IPR-Sachnormen und andere Ausnahme von der gewöhnlichen Anknüpfung im internationalen Privatrecht, Schulthess, Zurique, 1975, p. 132-184. ${ }^{10}$ Veja meu artigo in RT 788, p. 11 e seg.

"Veja no Brasil, o livro de Carvalho, Ana Paula Gambogi, Contratos via Internet, Belo horizonte, Del Rey, 2001, p. 21 e seg. Os alemães denominam o comércio eletrônico de "espaço negocial eletrônico" (elektronische Gerschaeftsverkehr), Steckler, Brunhilde, Grundzuige des EDV-Rechts, Vahlen, Munique, ,1999, p. 200 ou de negócios através da Internet (geschaeftsverkehr über das Internet), WIMMER, Norbert e GERHARD, Michael, Der Online-Provider im neunen Multimediarecht, Nomos, Baden-Baden, 1998, p. 135 
Efetivamente, desde a década de 90, há um espaço novo de comércio com os consumidores, ${ }^{12}$ que é a Internet, as redes eletrônicas e de telecomunicação de massa. ${ }^{13}$ Trata-se do denominado "comércio eletrônico", comércio entre fornecedores e consumidores realizado através de contratações à distância, as quais são conduzidas por meios eletrônicos (e-mail etc.), por Internet (on line) ou por meios de telecomunicações de massa (telemarketing, $\mathrm{TV}, \mathrm{TV}$ a cabo, etc.), sem a presença física simultânea dos dois contratantes no mesmo lugar (e sim à distância). ${ }^{14}$

A dificuldade estava em abarcar este complexo e rico fenômeno do comércio eletrônico de consumo sob uma só denominação e ao mesmo tempo identificar o "suficientemente novo", pois o meio eletrônico (ou televisivo, telepático ou por cabo) é apenas um veículo a mais para a contração à distância entre o consumidor e o fornecedor, contratação

que já conhecemos desde os catálogos e as vendas por reembolso postal. Dificuldade em identificar o suficientemente "específico" nesta contratação à distância envolvendo produtos e serviços, pois ninguém duvida que o comércio eletrônico de consumo, muitas vezes denominado pela expressão em inglês B2C (bussines-to-consumers), ${ }^{15}$ utiliza-se também de contratos de adesão e condições gerais contratuais $^{16}$ e, em matéria de serviços de informação ou de provimento de acesso à Internet, também são contratos cativos de longa duração. A dificuldade estava, pois, em diferenciar estes contratos "do comércio eletrônico" dos fenômenos de massificação contratual anteriormente analisados, uma vez que os contratos "eletrônicos" também são contratos típicos dos atuais tempos pósmodernos.

Inspirou-me a abundante doutrina sobre o tema. A doutrina italiana está convencida que

${ }^{12}$ Como ensina Steckler, p. 278, os meios usados para esta contratação a distância podem ser o telefone (com pessoas ou gravações, voice-mail, audiotexte etc.), rádio ou telefone com imagens, videotexto, microcomputadores, televisão, com teclado ou tela de contato, e-mail, telefax, teieshoping e outras técnicas semelhantes.

${ }^{13}$ Note-se que a Lei Modelo da UNCITRAL para o comércio eletrônico (UNCITRAL Model Law on Eletronic Commerce), que é voltada para o comércio internacional e inter-empresários, tanto que sua nota de rodapé explicita que as normas previstas não revogam ou atingem qualquer norma visando a proteção dos consumidores $(* *$ This Law does not override any rule of law intended for the protection of consumers), define em seu art $2^{\circ}$ que o comércio eletrônico tem como base a transferência de computador para computador (EDI) de informações usando um código standard para estruturar a informação (Art.2, b - "Eletronic data interchangeEDI" means the eletronic transfer from computer to computer of information using an agreed standard to structure the information) e que os dados transferidos são informações geradas, enviadasm, recebidas ou guardadas em forma ou meio eletrônico, optico ou similar (Art. 2, a-"Data message" means informations generated, sent received or stored by eletronic, optical or similar means including, but not limited to, eletronic data interchange (EDI) eletronic mail, telegram, telex or telecopy), Veja Law Commision, part one, p.139 e 140.

${ }^{14}$ Elementos retirados da Diretiva 97/7/CE, de 20 de maio de 1997 sobre contratação à distância (Widmer/ Baehler, p. 179 e seg.) e dos comentários de REICH, Norbert e NORDHAUSEN, Annette, Verbraucher und Recht in elektronischen Verkehr $(e G)$, Baden-Baden, Nomos, 2000, p. 36 sobre o que denominaram colocação eletrônica à distância de produtos e serviços ("elektronische Fernabsatz")

${ }^{15}$ Veja curso de Haia do advogado da Microsoft, SMITH, Bradford, The third industrial revolution: Law and policy for te Internet, in Recueil, 2000, T. 282, p. 260 a 265

${ }^{16}$ Veja SANTOS, Manoel J. Pereira do e - e-ROSSI, Maria Delapieve, Aspectos legais do comercio eletronico, in RDC 35, 2000, p. 123 e seg. Estes autores,p. 108, definem "contratos eletrônicos como os "negócios jurídico bilaterais que utilizam o computador, como mecanismo responsável pela formação e instrumentalização do vínculo contratual".

Revista da Faculdade de Direito da UFRGS, v. 21, Março/2002

A proteção do consumidor de produtos e serviços estrangeiros no Brasil:

estes contratos são "contratos desumanizados" (Oppo) e "sem acordo" (Irti).$^{17}$ Seriam contrato em que o fornecedor não teria mais "rosto", não mais apareceria (ou poderia mesmo não existir) fisicamente ou territorialmente, ${ }^{18}$ pois alguns fornecedores globais são redes de distribuição sem sede fixa. Os contratos à distância no comércio eletrônico seriam apenas um sub-tipo dos contratos "automatizados", contrato realizados diretamente com "computadores" (como os contratos de Home-banking) ou com máquinas de respostas (como os contratos por telefone com respondedores automáticos), contratos "em silêncio" ou "sem diálogo" (expressão de Irti), conduzidos mais pela imagem, pela conduta de apertar um botão, do pela linguagem. Certo é que nestes contratos há acordo de vontade, há vontade, mesmo que de adesão e "de conduta social típica", logo, há contrato, mesmo que unilateralmente elaborado e muitas vezes não acessível ao consumidor. Há uma bilateralidade essencial apesar da unilateralidade tão visível. Há bilateralidade de vontades, pois apesar do fornecedor ser "virtual" e do consumidor ser "massificado", apesar do oferecer e do eleger serem mais "automatizados", apesar do direito abstrair mais do plano da validade, e considerar

mais a confiança despertada, a declaração de oferta realizada, do que a vontade interna do fornecedor, considerar mais a conduta social do consumidor, do que a capacidade deste ou de quem atuou por ele ou no seu computador, há um contrato no plano da existência, juridicamente relevante e que produzirá efeitos - e muitos- no plano da eficácia. O contrato final é "velho", o método de contratação é atual, e o meio de contratação - e por vezes de cumprir a prestação imaterial- é que é "novo".

Neste sentido, o novo aqui, parece-me, é a soma de métodos massificados e pósmodernos de contratação. $O$ novo aqui é o fato de -em um revival da obrigação de dar. Novamente a maioria destes contratos do comércio eletrônico envolvem obrigações de dar e não duram no tempo, isto é, são contratos de prestação imediata e pagamento único (com a ajuda do sistema de cartão de crédito), muitos são contratos de compra e venda (por ex: aquisição de livros, Cds, DVDs, ou mesmo a compra de um software/programa/antivírus, nos chamados contratos informáticos ${ }^{19}$ (pois o produto é enviado pelo meio eletrônico), mas que envolvem "produto imaterial" ( o software, por definição legal, as músicas, ebooks, filmes,

${ }^{17}$ Sobre a controvérsia entre Irti e Oppo, veja FRESNEDA SAIEG, Mónica e HERNÁNDEZ, Carlos A., "La Sobre a controvérsia entre Irti e Oppo, veja FRESNEDA SAIEG, Mónica e HERNÁNDEZ, Carlos A., "La
protección del consumidor en los contratos a distancia celebrados por medios informaticos", in Revista de protección del consumidor en los contratos a distancia celebrados por medios informaticos", in Revista de
responsabilidad civil y seguros (Buenos Aires, La Ley), nr. 5, set./oct., 2001/Hernandez, p. 62-63. A amistosa disputa começou com o instigante artigo de Irti, "Scambi senza acordo"(1998), respondido por Oppo com o artigo "Disumanizzazione del contrato", (1998) e replica de Irti, "è vero ma...(Replica a Giorgio Oppo)", in Revista di Direitto Civile, anno XLV, nr. 2, 1999, p. 273 e seg.

${ }^{18}$ Veja sobre territorialidade e Internet, GROSSFELD, Bernhard, Global Accounting: Where Internet meets Geography, in te American Journal of Comparative Law, 200, vol. 48, p. 261-306.

${ }^{19}$ Como ensina BRIZZIO, Claudia R., La informática en el nuevo derecho, Buenos Aires, Abeledo-Perrot, 2000, p. 34, a expressão informática é uma criação advinda união de "informação automatizada" e descreve todo o tipo de tratamento de informação por suportes automatizados em computadores. A autora define contratos informáticos: "se entiende por contrato informático al que tiene por objeto bienes o serviços informáticos" (Brizzio, p. 42, nota 90) e citando Davara Rodrguez, inclui lodos os contratos envolvendo bens materiais serviços (dunción

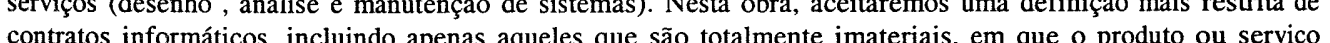

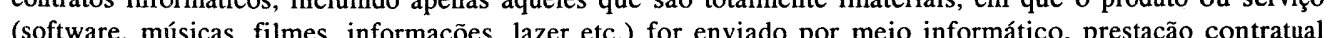
totalmente sem materialização até a chegada ao consumidor (paperless e materialless).

Revista da Faculdade de Direito da UFRGS, v. 21, Março/2002 
clips etc.), em um revival destes contratos frente aos contratos cativos de longa duração , fenômeno antes comentado, que em sua maioria são contratos de serviço e de prestação prolongada no tempo.

O "específico e substancialmente diferente" aqui é o meio eletrônico utilizado, que permite de um lado interatividade, de outro, algo analógico às correspondências ou reembolso postal, no uso de e-mail na contratação à distância com intervalo temporal. Também há que se destacar o uso metodológico da imagem, da conduta social típica e do silêncio dos consumidores. Assim, entrando no mundo virtual dos sites(imagens), o caminho é repleto de imagens (e linguagens) e um simples tocar no teclado significa aceitação, um simples continuar um caminho virtual de imagens, sons e de mínimas palavras, significa uma declaração de vontade tácita, um simples continuar no site, em silêncio, abrindo wraps sem protestar ou cortar a conexão, pode significar um determinado tipo de contratação ou declaração negativa ou positiva. Há que se destacar ainda como novo e específico que o meio eletrônico, onde ocorrerá a negociação-virtual e contratação-virtual, também modifica os conceitos de tempo real, impondo o tempo virtual, de território, impondo a rede global como "lugar do contrato", em contrato já denominado de desterritorializado, internacional ou nacional conforme as partes, não conforme o lugar da conclusão do negócio (Art. 9, $\$ 2^{\circ}$ da LICC), pois

as ofertas nos sites são "globais" em rede e não encontram mais limites territoriais ou nacionais. ${ }^{20}$ Acabei escolhendo a denominação "contratos do comércio eletrônicos", em homenagem ao livro de Michel Vivant, ${ }^{21}$ obra que tem como finalidade o estudo dos contratos comerciais e de consumo, com a diferença que me concentrarei aqui nos "contratos do comércio eletrônicos" envolvendo consumidores na sociedade brasileira.

\section{A. Tipos de contratos de con- sumo à distância no comércio eletrônico e seu regime no Direito material brasileiro}

1. Os diferentes tipos de contratos à distância no comércio eletrônico realizados por consumidores.

Vivant analisa os seguintes contratos do comércio eletrônico que, por envolverem consumidores, nos interessam: 1 . Os contratos de acesso técnico às redes eletrônicas (contrato entre o consumidor e um fornecedor de acesso - servidores, TVs cabo e outros), ${ }^{22} 2$. o contrato de venda on-line, ${ }^{23}$ venda de produtos materiais, que serão entregues a posteriori no

${ }^{20}$ Veja GROSSFELD, Bernhard, Global Accounting: Where Internet meets Geography, in te American Journal of Comparative Law, 200, vol. 48 , p. 261-306

${ }^{21} \mathrm{O}$ autor francês também procura uma certa originalidade nestes contratos, assim afirmando VIVANT, Michel, Les contrats du commerce électronique, Litec, Paris, 1999, p. 4: "Nous allons examiner commerce électronique qui présentent une certaine originalité, originalité qui peut tenir à leur objet, vraiment neuf, comme a l"éclairage' que l'Internet peut ler conférer. Mais le domaine contractuel est, par nature même, celui de la liberté. Ce qui veut dire qu'il n'y a nulle autre borne à la création de contrats, nouveaux ou revisités...,que l'imagination même des praticiens."

${ }^{22}$ Vivanat, p. 13 e seg.

${ }^{23}$ Vivant,p. 89

Revista da Faculdade de Direito da UFRGS, v. 21, Março/2002 local indicado pelo consumidor e venda de produtos imateriais (software, etc.) a ser enviado pelo mesmo meio eletrônico; 3 . contratos de bens "informacionais", ${ }^{24}$ bens totalmente desmaterializados, como músicas, revistas online, educação à distância, acesso informações, a imagens, filmes, trailers, histórias em quadrinhos, jogos, videogames, etc. Incluiríamos também 4. os contratos de prestação de serviços on-line ou por Internet como contratação com agências de viagens, transportadoras, seguradoras, bancos financeiras, contratos não tratado por Vivant.

Nos contratos de acesso dos consumidores (pessoas físicas) à Internet e redes eletrônicas os temas mais freqüentes de interesse dos consumidores são: as informações sobre os diferentes tipos de planos, a velocidade, qualidade (uso municipal, em deslocamentos, em outros países, webmail etc.) e quantidade exata da prestação (de horas, grupos, newgroups, e-mails, capacidade de estocagem, etc.), as informações de instalação e uso, assim como para acessar a assistência técnica 24horas. Os problemas mais freqüente são as mudanças do conteúdo contratual e do preço, as interrupções do sistema, a demora para acessar, a velocidade esperada não confirmada, o não-bloqueio correto de conteúdos restritos e sites, o envio de e-mails

não solicitado, a quebra do sigilo nos endereços eletrônicos e das senhas de acesso, ${ }^{25}$ a nãocripografia estipulada, a falha do web-mail, a não estocagem e a perda de informações, os vírus e cookies, os hackers, a venda casa de equipamentos para rápido acesso, as cláusulas penais, a formação não informada do preço. ${ }^{26}$

Nos contratos de venda on-line e de bens informáticos aos consumidores, os produtos vendidos podem ser materiais, que serão entregues a posteriori no local indicado pelo consumidor e venda de produtos imateriais (software, etc.), ${ }^{27}$ cujo envio é imediato ou retardado no tempo, mas pelo mesmo meio eletrônico. Os problemas mais comuns são não entrega, ou entrega em endereço errado, as taxas não especificadas de correio ou $\mathrm{d} e$ recebimento, o retardo na entrega, a falta de sanção pelo retardo na entrega, a falta de garantia para o produto, a impossibilidade de executar o direito de arrependimento (produto aberto, software já enviado, endereço incongruente ou incompleto), a lei aplicável e a jurisdição competente, por vezes até uma jurisdição arbitral virtual compulsória, a venda casada, a recusa de venda, a falha na segurança com os dados do consumidor, dados privados e dados sensíveis, como o seu número de cartão de crédito, a falha na cobrança no cartão de crédito (cobrança a mais, cobrança antes da

${ }^{24}$ Vivant, p. 105 e ses.

${ }^{25}$ Veja decisão recente do TJ-RSJ?Rs sobre o tema, em que o provedor mesmo entra com ação contra usuário comercila seu que quebrou indevidamente as senhas e endereços dos outros usuários para enviar publicidade comercial. "Ação ordinanta de obrigação de não fazer, cumulada com tutela antecipada e pedido cominatoriio. Prova

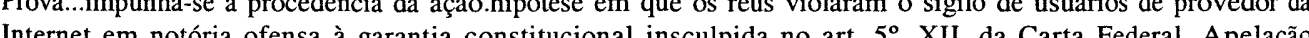
lesporvid" (TJ/RS, Ap.C 70001918333, j. 08.05.2001, Des. Ferando Braf Henning Júnior).

${ }^{26}$ Veja VIVANT, p. 17, 18 e 19. Como alerta FÉRAL-SCHUHL, Christiane, Cyber Droit- Le droit à l'épreuve de l'Internet, 2. Ed., Dalloz-Dunod, Paris, 2000, p. 171, estes contratos de acesso à Internet são tão conflituais que o governo francês interveio para impor informações mínimas e proibir certas práticas comerciais. Veja no Brasil, trabalho pioneiro de Antonio Joaquim Fernandes.

${ }^{27}$ Veja VIVANT,p. 89 e seg. 
entrega etc.), as diferenças entre as fotografias do site e os produtos recebidos, a compra involuntária ao apertar o incône, o erro não sanável na contratação etc.

Nos contratos de bens "informacionais", ${ }^{28}$ bens totalmente desmaterializados como músicas, ebooks, revistas on-line, acesso a informações e bancos de dados, a imagens, filmes, trailers, histórias em quadrinhos, jogos, videogames, etc. os problemas mais comuns além dos outros anteriormente mencionadosseriam as próprias condições de uso do bem transmitido (cópia, dowload etc.), a garantia de prestabilidade dada, os erros na contratação o direito de arrependimento, a desatualização ou imprecisões dos bancos de dados, a demora na prestação das informações, do lazer etc. ${ }^{29}$ Um regime especial, com responsabilidade qualificada dos fornecedores, é o dos contratos por Internet visando conselhos, aconselhamento (financeiro, na compra de produtos complexos ou em atividade como corretor), pareceres (econômicos, estatísticos, advocatícios etc.), ${ }^{30}$ tratamentos (medicinais, psicológicos, médicos etc.). ${ }^{31}$ Os contratos envolvendo educação à distância através da Internet também envolvem questões espe-cíficas, geralmente reguladas em leis especiais, envolvendo garantias, reconhecimento dos diplomas, títulos, qualidade e quantidade da informação, direitos autorais, modos de cobrança e proibindo certas práticas comerciais nestes contratos educacionais. ${ }^{32}$ Também mencione-se que os contratos envolvendo jogos de azar, prêmios, práticas comerciais proibidas em alguns países (venda em bola de neve etc.) e lazer com conteúdos adultos ou pornográficos, envolvem a aplicação de normas de ordem pública $\mathrm{e}$ proibições específicas de cada país envolvido. ${ }^{33}$

Nos contratos de prestação de serviços on-line ou por Internet, como contratação com agências de viagens, transportadoras, seguradoras, ${ }^{34}$ bancos e financeiras, ${ }^{35}$ os problemas mais comuns são os relacionados à
${ }^{28}$ VIVANT, p. 105 e seg.

${ }^{29}$ Como aletrta SCHMITZ, Dirk, Die vertraglichen Pflichten und die Haftung der Informationsanbieter im Internet, Stuttgart, Kolhammer, 2000,p. 131 e seg., se as informações e dados são gratuítos na Internet e realmente não remunerados indiretamente, o regime é diferenciado, análogo às doações e liberalidades do direito civil geral, mas com um regime sui generis de responsabilidade civil (p.142).

${ }^{30}$ Sobre o tema da prestação de serviços advocatícios pela Internet, veja artigo específico de Maria Cristina Zucchi, in DELUCCA, Newton e SIMÃO,Adalberto, DeLucca e Simão, Direito e Internet-Aspectos Jurídicos Relevantes, São Paulo, Edipro, 2000 Direito e Internet-Aspectos Jurídicos Relevantes, São Paulo, Edipro,
2000, fInternet, p. 329 a 350.

${ }^{31}$ Assim alerta SCHMITZ, p. 135 e seg.

${ }^{32}$ Assim aletra REICH/NORDAUSEN, p. $64 \mathrm{e} \mathrm{seg.}$

${ }^{33}$ Sobre o tema veja WIMMER, Norbert e GERHARD, Michael, Der Online-Provider im neunen Multimediarecht, Nomos, Baden-Baden, 1998/Michael, p. 40 e seg.

${ }^{34}$ Sobre seguros-online, veja WINTER, Gerrit, "Internationale Online-Versicherungs als Korrespondenzsversicherung", in Versicherungsrecht 2001, Gerrit, "Internationale Online-Versicherungs als Korrespondenzsversicherung", in Versicherungsrecht 2001, p. 1461 e seg.

${ }^{35}$ Como esclarece SPINDLER, Gerald (Org.), Vertragsrecht der Internet-Provider, Colonia, 2000,p. 341, somente os contratos bancários com consumidores e de investimento receberam um tratamento especial na Diretiva te os contratos bancários com consumidores e de investimento receberam um tratamento especial na Diretiva
européia 200/31/CE (Art. 3,IV), face a especial vulnerabilidade dos consumidores, aplicando-se suas normas imperativas, quebrando o princípio da lei do país de origem (Herkunftslandprinzip).

Revista da Faculdade de Direito da UFRGS, v. 21, Março/2002 qualidade, quantidade, tempo e modo da prestação do serviço, e a segurança deste, em especial, tratando-se de home-banking, financiamento on line ou por automáticos bancários. ${ }^{36}$ Interessante observar que neste tipo de contratação, aplica-se o direito de arrependimento e reflexão (Art. 49 do CDC) Assim resultaria, também no Brasil, se uma empresa aérea vende em seu site um bilhete ou faz um financiamento para o cliente, há direito de arrependimento do consumidor-leigo, ${ }^{37} \mathrm{da}$ mesma forma, se o consumidor faz um leasing ou aluga um automóvel ${ }^{38}$ ou mesmo faz um empréstimo/mútuo on-line no seu home banking. ${ }^{39}$ Segundo Meents, problemático é apenas o arrependimento em matéria de fornecimento de informações mensais ou revistas. Nestes casos, usam os doutrinadores europeus uma analogia ao fornecimento de crédito mês a mês e o direito de arrependimento renova-se, sempre que um novo mês inicia. ${ }^{40}$

Santos e Rossi classificaram estes contratos do comércio eletrônico com execução no ambiente virtual de "comércio eletrônico direto", lembrando ainda que o pagamento se

faz geralmente mediante o uso de cartões de crédito ou Eletronic Fund Transfer-EFT, reforçando a natureza intangível do objeto contratual e sua execução.

Cesar Santolim, em sua pioneira obra de 1985, classificou os contratos "por computador", em 3 tipos: aquele que usa o computador como "simples meio de comunicação", e se assemelha na disciplina aos contratos por carta, correspondência comercial, à distância típicos; aquele que usa o computador "como local de encontro de vontade já aperfeiçoadas", e aquele em que o computador é "auxiliar no processo de formação da vontade (Contratos por computador stricto sensu)". ${ }^{42}$

Santos e Rossi destacam que a contratação neste espaço eletrônico podem ser interpessoais, interativas e intersistêmicas ${ }^{43}$ as duas primeiras podem ser de consumo e interessam-nos em especial, já as intersistemicas, com sistemas aplicativos previamente programados pelos fornecedores, são típicas de contratos entre comerciantes e com finalidade

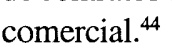

${ }^{36}$ Veja TIMM, Lucianno Benetti, A prestação de serviços bancários via Internet (home banking) e a proteção do consumidor, in Revista de Direito do Consumidor, vol. 38 (2001), Home banking, p. 74 e seg. e meu artigo "Sociedade de informação", p. 49 e seg. A análise clássica é de GAVALDA, p. 225 e seg.

${ }^{37}$ Este direito é comum na europa, veja MEENTS, Jan Geert, Verbraucherschutz bei Rechtsgeschäften im Internet, Editora Otto Schmidt, Colônia, 1998, p. 31.

${ }^{38} \mathrm{O}$ direito de arrependimento em matéria de leasing também existe na Europa, nestes casos, veja Meents, p. 32.

${ }^{39}$ Este direito de arrependimento existe tamb'eme na Europa, veja MEENTS, p. 245 e seg.

${ }^{40}$ Assim ensina MEENTS, p. 38 e 40 e 41.

${ }^{41}$ SANTOS e ROSSI, p. 115.

${ }^{42}$ SANTOLIM, Cesar Viterbo Matos, Formação e Eficácia Probatória dos Contartos por computador, São Paulo, Saraiva, 1995,p. 24 e 25 .

${ }^{43}$ SANTOS e ROSSI, p. 111.

${ }^{44}$ Assim SANTOS e ROSSI, p. 112: "Nas contratações intersistêmicas, a comunicação eletrônica se estabelece entre sistemas aplicativos previamente programados, estando ausente a ação humana no momento em que a entre sistemas aplicativos previamente pro
comunicação propriamente dita acontece.

Revista da Faculdade de Direito da UFRGS, v. 21, Março/2002 

dados, suporte ao usuário, sistema de pesquisa

\section{Os diferentes elementos dos contratos à distância do comércio eletrônico de consumo} temos um outro tipo de contrato pós-moderno,
Já os recentes estudos de matéria tributária e da $\mathrm{OECD}^{45}$ afirmam que as transações por meio eletrônico com consumidores e que interessam a este estudo podem ser as seguintes: tratamento eletrônico de encomendas de produtos materiais; pedido eletrônico e download de produtos digitais; pedido eletrônico de atualizações e itens adicionais; pedido de sof ware ou outro produto digital para usuário único manutenção de sotf ware; armazenagem de e recuperação de dados; fornecimento de dados exclusivos ou outros dados com forte valor agregado, acesso eletrônico a assessoria profissional; informações técnicas, entrega de informações; acesso a um web interativo; acesso a um portal de compras on-line, acesso a leilões on-line; sites com ofertas de produtos em anexo, transmissão de dados contínuos (em tempo real) através da web; provedores de acesso à Internet.

Como se observa o chamado "comércio eletrônico" é realizado através de contratações à distância, por meios eletrônicos (e-mail etc), por Internet (on line) ou por meios de telecomunicações de massa (telemarketing, TV, TV a cabo, etc.), é um fenômeno plúrimo, multifacetado e complexo, nacional e internacional, onde há realmente uma certa "deshumanização do contrato" ("disumanizzazione del contratto"). ${ }^{46}$ A expressão escolhida pela doutrina italiana choca, e está sua principal finalidade. Assim como Ghersi denominava de "contrato sem sujeito", o primeiro tipo de contrato pós-moderno, aqui

em que a impessoalidade é elevada a graus antes desconhecidos e no qual todas as técnicas de contratação de massa se reunirão: do contrato de adesão, das condições gerais contratuais, ao marketing agressivo, à catividade do cliente, à internacionalidade intrínseca de muitas relações, à distância entre o fornecedor e o consumidor. Se temos aqui presentes os elementos da contratação massificada e geral, da pressão e da distância, fenômenos já conhecidos, por exemplo, com a venda por correspondência, por catálogo e outras, somente uma descrição mais detalhada do iter da "contratação no comércio eletrônico" pode esclarecer como este "meio" "'instrumento" de contratação pode ser tão especial a ponto de criar um fenômeno próprio e diferente de seus predecessores.

O fenômeno é novo por sua fluidez, complexidade, distância, simultaneidade ou atemporariedade, desterritorialidade e objetividade ou autonomia. Vejamos, a contratação é a distância, e esta distância televisiva ou telemática traz uma nova espécie de pressão (Zwang). Não a pressão do vendedor em sua porta, mas do fato da oferta estar dentro de sua casa, no seu trabalho, no seu espaço privado, nas suas férias, atemporalmente, dia e noite, em todos os lugares do mundo, onde a oferta negocial puder ser acessada ou vista. A distância física entre o fornecedor e o consumidor é enorme fator de debilidade informativa, as informações disponíveis são aquelas escolhidas pelo fornecedor e acessadas com uniformidade. A distância física entre o fornecedor e o consumidor é fator de insegurança, tanto quanto ao efetivo envio do produto (por exemplo: livros, CDs, DVDs, Automóveis, eletrodomésticos, soft ware, peças de um leilão eletrônico, etc.), ou serviço (informações, filmes, músicas acesso à

${ }^{45}$ A sistematização a seguir foi realizada por Atílio Dengo, advogado da "portoweb", com base nos estudos da Atílio, Tributação do Comércio Eletrônico, Diss. de Mestrado, UFRGS, 2001, p. 206 a 254.

${ }^{46}$ Assim a expressão de OPPO, p. 525, citando Natalino Irti e sua expressão "scambi senza accordo".

Revista da Faculdade de Direito da UFRGS, v. 21, Março/2002 $\mathrm{OECD}$, da qual foram retirados somentes as transaçōes que, na visão da autora, são de consumo, veja DENGO,
Internet etc.) , à lisura da forma de pagamento e do relacionamento pós-contratual (débito no cartão de crédito, clonagem de cartões de crédito, acesso à dados privados, garantias do pós-venda etc.), quanto em relação à lei destes fornecedores "eletrônicos" localizam-se no exterior.

A fluidez ou desmaterialização da contratação é um elemento a ser considerado: 0 fornecedor não aparece materializado através de um vendedor, o fornecedor não tem mais "cara", tem sim uma marca, um nome comercial, ou televisivo, uma estratégia de telemarketing. O fornecedor não tem endereço comprovável, mas apenas 'informável '. Do fornecedor não se sabe sequer se é realmente um profissional, pois dada a diminuição dos custos de oferta transação que a Internet traz, ${ }^{47}$ o fornecedor pode ser um "iniciante" ou mesmo um adolescente "genial", o fornecedor pode ser, em resumo, um outro consumidor, como no caso dos leilões por Rede ou dos negócios eventualmente realizados em Chats ou salas virtuais.

Outro elemento a considerar-se é complexidade técnica e jurídica deste tipo de aplicável ao contrato, uma vez que muitos uma determinada imagem, um marketing virtual contratação à distância. Para lá do clickagreement, que seria contratado com um simples bater de uma tecla no lugar indicado, o comércio eletrônico é pleno de surpresas, desde os contratos "encapsulados" o wraps agreements, que só são visualizados após a contratação, contratos por série de clicks em cadeia, aos cookies, presentes desvendadores dos visitantes de determinado site site ou portal, aos contratos que só são virtuais e nunca podem ser realmente "captados" e perenizados pelo consumidor, tendendo -ou facilitando- a que o fornecedor mude o conteúdo contratual com o passar do tempo virtual. ${ }^{48}$

Quanto à complexidade jurídica, mister frisar que todos os contratos não solenes podem ser hoje realizados por e-mail, on line, por Telefone, Cabo ou por Internet. Em especial as contratações bancárias, as envolvendo financiamento, crédito e renegociação de dívidas, devem receber especial atenção. ${ }^{49}$ Trata-se do mais novo efeito da sociedade de informação $0^{50} \mathrm{em}$ matéria bancária. Nos últimos dez anos, o mercado brasileiro de serviços financeiros modificou-se drasticamente ${ }^{51}$. Verifica-se um aumento substancial no uso de cartões de crédito, cartões eletrônicos , atendimento bancário à distância, via telefone
${ }^{47}$ Veja sobre o tema, excelente, LORENZETTI, Ricardo, Comercio electrónico, Buenos Aires, Abeledo-Perrot, 2001,Comercio eletrónico, p. 26 a 28.

${ }^{48}$ Veja LORENZETTI, Comercio eletrónico, p. 202

${ }^{49}$ Veja sobre o tema meu artigo "sociedade de informação e serviços bancários" e in TIMM, Lucianno Benetti, A prestação de serviços bancários via Internet (hHome banking) e a proteção do consumidor,, in Revista de Direito do Consumidor, vol. 38 (2001), p.79 e seg.

${ }^{50}$ VejaSobre sociedade de informação, veja CASTELLS, Manuel, End of Millennium (The Information Age: Economy Society and culture, volume III), Blackwell P., Oxford, 1998, p. 1. , que assim a comenta: “...this is indeed a time of change a technological revolution, centered around information, has transformed the way we think, we produce, we consume, we trade, we manage, we commu nicate, we live, we die, we make war, and we make love. A dynamic global economy has been constituted around the planet, linking up valuable people and activities from all over world, while switching off from the networks of power and wealth, people and territories dubbed as irrelevant from the perspective of dominant interests.." ${ }^{51}$ Cf. MARQUES,Cláudia Lima Marques, 'Les contrats de crédit dans la législation brésilienne de protection du consommateur', in lain Ramsay (ed.), Consumer Law in the Global Economy (Ashgate-Dartmouth, Aldershot,
England, 1997), pp. $321-348$. 
ou Internet, e no número geral de clientes bancários. Da mesma forma, ocorreu também, por parte do governo brasileiro, uma fort desregulamentação e privatização do sistema financeiro e creditício, aumentando assim a competição entre instituições financeiras, no mesmo momento em que a defesa do consumidor foi finalmente regulada através do Código de Defesa do Consumidor (Lei 8.078/ 90). Há também o chamado Código do cliente bancário, a Res. 002878 do Bacen, que "dispõe sobre procedimentos a serem observados pelas instituições financeiras e demais instituições autorizadas a funcionar pelo Banco Central do Brasil na contratação de operações e na prestação de serviços aos clientes e ao público em geral."

Lorenzetti, em interessante resumo, ${ }^{52}$ destaca, como elementos novos e conjuntos deste fenômeno a distância entre fornecedor $\mathrm{e}$ consumidor, a simultaneidade ou atemporariedade da oferta e da aceitação, assim como da contratação em si, a desterritorialidade da contratação, realizada em "território" virtual, no écran do consumidor, mas em realidade de execução à distância e a objetividade ou autonomia das duas vontades exteriorizadas, seja frente a uma máquina, no fax, no telefone ou em qualquer outro meio virtual.

\section{B. Formação do vínculo e disci- plina material destes contra- tos}

Inicialmente, mister frisar que a disciplina destes contratos à distância no comércio eletrônico é a mesma que a dos outros contratos à distância, estando regulados no CDC. Necessário é, porém, destacar a vulnerabilidade

${ }^{52}$ LORENZETTI, Comercio eletrónico,p. 163 e seg. especial do consumidor quando se utiliza do meio eletrônico. Em outras palavras, o meio eletrônico, automatizado e telemático, em si, usado profissionalmente pelos fornecedores para ali oferecerem seus produtos e serviços aos consumidores, representa aos consumidores leigos, um desafio extra ou vulnerabilidade técnica. $O$ consumidor não é mesmo que se considere- um especialista ou técnico em computadores e na Internet.

Esta "falha tecnológica" é geral, mas não desanima, ao contrário, fascina a maioria. É típica da pós-modernidade. Apesar desta "falha tecnológica" ou vulnerabilidade frente ao meio virtual milhares de consumidores, sem medo, negociam, compram e participam até mesmo de leilões e outros "divertimentos" consumistas sem censura, através da rede mundial da Internet. Atuam eles sem conhecimento técnico, sem fronteiras, sem território, sem passado, sem experiência e com uma fluída confiança, justamente no Direito "do Consumidor", e em uma vaga (e muitas vezes inexistente) proteção "internacional" dos mais fracos, confiando nas respostas pelo menos razoáveis que a Justiça dará. É um contexto novo de superficialidade, hedonismo consumista e insegurança pósmoderna.

\section{Proteção quando da formação do vínculo à distância no comércio eletrônico de consumo}

Efetivamente, estes muitos consumidores que hoje negociam neste mundo de consumo eletrônico necessitam de uma proteção, e os aplicadores do Direito devem conhecer e dominar as linhas básicas que regem estas e outras negociações de consumo, sejam nacionais ou internacionais. Proteger e melhorar a posição jurídica contratual deste negociador mais fraco e leigo no comércio eletrônico, que é o consumidor pessoa física residente no Brasil, parece ser a finalidade maior da doutrina brasileira e dos projetos de leis existentes sobre o assunto. Como ensinam Lorenzetti e o advogado da Microsoft, parece haver consenso universal que o consumidor no comércio eletrônico deve receber o mesmo grau de proteção que já alcançou em seu país no comércio normal. ${ }^{53}$

Como destaca o professor alemão Norbert Reich, ${ }^{54}$ existem pelo menos cinco diferentes constelações de procedimentos para que esta contratação à distância no comércio eletrônico com consumidor realize-se: a) ou o consumidor se dirige a um fornecedor conhecido (rede de lojas de eletrodoméstico, de roupas, fabricante da carros, marcas famosas etc.) por meio eletrônico; b) ou o consumidor encontra a publicidade no site do fornecedor, quando está surfando na Internet e se interessa pela oferta; c) ou a publicidade enviada por email leva o consumidor virtual ao sitio de Internet do fornecedor; e) ou a publicidade enviada por e-mail já contém o link fornecedor que o

\section{consumidor então acessa.}

Quanto à da formação do contrato, a doutrina ${ }^{55}$ destaca os vários (e diferenciados) momentos da fase pré-contratual, que interessam ao direito do consumidor, a começar pela oferta ou proposta pública, que representam os antes mencionados sites, links, e-mails, a publicidade, os spams e outras manifestações virtuais de 'vontade negocial' dos fornecedores do mundo inteiro. ${ }^{56}$ Considerando que estas manifestações de vontade negocial dos fornecedores contêm os elementos da oferta e despertam a confiança dos consumidores, são mais do que simples "convites públicos à oferta". Segundo pareceme ser a primeira qualificação pela lex fori (lei brasileira), serão consideradas ofertas, no sentido do Art. 30 do CDC (e, parece-me, também serão consideradas propostas, no sentido do Art. 429 do Código Civil de 2002, se comerciais e puramente civis).$^{57}$

As conclusões do $\mathrm{V}$ Congresso Brasileiro de Direito do Consumidor, de Belo Horizonte, em 2000, já foram pela auto-aplicação das normas de direito do consumidor brasileiras
${ }^{53}$ Veja LORENZETTI, Comercio eletrónico, p. 188 e seg. e SMITH, Bradford, The third industrial revolution: Law and policy for te Internet, in Recueil de l'Haye, 2000, T. 282, p. 324 citando o Joint statement on eletronic Commerce da Austrália e do Japão, as recomendações da OECD, as regras da união européia, as quais poderíamos unir os esforços da UNCITRAL, UNIDROIT e da Conferência de Haia.

${ }^{54}$ REICH/NORDHAUSEN, p. 4.

${ }^{55}$ Veja, por todos, LORENZETTI, Comeércio eletrónico, p. 175 e seg.

${ }^{56}$ Veja, por exemplo, a decisão do Tribunal de Hamburgo (OLG Hamburg), de 22.02.2001, que cobnsiderou que um link só pode ser incluindo em um site, se for esta a vontade negocial do conectado, veja NJW-RR, 2001, p. 1198. Tambe'me considerando qualquer publicidade online vontade negocial e o lugar onde despertar a confiança como conexão, veja LANDFERMANN, Hans-Georg, "Internet-Werbung und IPR, in Festchrift für das 75 Jahre
Max-Plank-Institut Hamburg, Nomos, Baden-Baden, p. 514.

${ }^{57}$ Considero que o Código Civil de 2002 não rege as relações de consumo, senão subsidiariamente e como base conceitual, neste sentido o Art. 429 do $\mathrm{CCBr} / 2002$ regularia as relações inter-empresárias (B2B) e as puramente civis (se assim consideradas as realizadas por dois 'consumidores-leigos' pela Internet, $\mathrm{C} 2 \mathrm{C}$ ). De qualquer maneira, vale a menção do referido novo Artigo: "Art. 429. A oferta ao público equivale a proposta quando encerra os requisitos essenciais ao contrato, salvo se o contrário resultar das circunstâncias ou dos usos. Parágrafo único. Pode revogar-se a oferta pela mesma via de sua divulgação, desde que ressalvada esta faculdade na oferta realizada." 
ao comércio eletrônico com consumidores.$^{58} \mathrm{E}$ considerando que qualquer consumidor residente no Brasil pode aceitar qualquer oferta do fornecedor, nacional ou estrangeiro, concluíram pela caracterização destas práticas negociais como oferta de consumo. ${ }^{59}$ o comércio em todo o globo de seus produtos e limitar a revogabilidade desta oferta, que a prática negocial de ofertar produtos e serviços pela Internet, em seus diversos modos, interativos e estáticos, é oferta de consumo, que pode ser aceita pelo consumidor a qualque A revogabilidade vai depender da lei aplicável ao caso, mas se sugere ao fornecedor já informar as condições da oferta na publicidade, site ou em importância os usos e costumes do meio estrangeiras (o que já ajuda a formação da
A preocupação da doutrina “jurisdicizar" estas práticas comerciais visando desperta a confiança dos consumidores Concorde-se com Lorenzetti, quando afirma que momento, nas condições da oferta realizada. ${ }^{60}$ meio eletrônico usado para tal. Aqui ganham pois que as ofertas de fornecedore internacionais geralmente são em língua

confiança do consumidor brasileiro de que está celebrando um contrato internacional), os prazos de reflexão variam conforme as legislações e usos locais e podem ser mais favoráveis ao consumidor brasileiro, servindo a lei brasileira como lei imperativa de uso subsidiário, se mais favorável ao consumidor aqui residente. A forma de perenizar a oferta também é diferente, pois, uma vez não aceita na forma usual (click, informação de certos dados etc.), a oferta pode ser retirada do site sem que o consumidor nada possa fazer, se não a aceitou devidamente, segundo os usos e condições gerais do fornecedor. Como se verifica, aqui o meio virtual, sua instantâneidade e interactividade, influencia o regime da oferta e aceitação.

Seja considerado oferta de consumo ou não, há que se considerar que estas práticas comerciais dos fornecedores fazem nascer deveres de boa-fé geral, como o de informação, identificação do ofertante, identificação de oferta comercial, cuidado com os dados do consumidor (dever de preservação da privacidade do consumidor, ${ }^{61}$ de proteger

${ }^{58}$ As conclusões, publicadas in Revista de Direito do Consumidor, vol. 35, p. 265, foram: "10.A argumentação em favor da aplicação da lei de domínio do fornecedor é inadequada, pois parte do pressuposto que a proteção e tutela do econômico, por imposição constitucional, devem ter por paradigma a defesa do consumidor. (aprovada por unanimidade)" e "11.As normas do CDC, como expressamente consignado em seu artigo $1^{\circ}$, são de "ordem pública e de interesse social", entre a ordem pública local e a ordem pública estrangeira o juiz deve preferir a ordem pública de seu país; as disposições do CDC, por serem normas de ordem pública, não podem deixar de ser aplicadas às relaçōes de consumo que envolvem consumidores residentes no território nacional, ressalvada a aplicação cumulativa da legislação estrangeira mais favorável. (aprovada por unanimidade)"

${ }^{59}$ As conclusões do painel foram "A prática do comércio eletrônico não prescinde de prévia autorização do ofertante para o dispor de seus produtos e serviços pela Internet. Isto não significa que o mesmo esteja a margem dos pré-requisitos legais determinados para a prática de atos de comércio. (aprovada por unanimidade)", "No momento em que a oferta suficientemente precisa foi veiculada pela rede mundial denominada internet, está o fornecedor a ela vinculado; não cabe a retratação do direito civil; é necessária a ciência do fornecedor da aderência do consumidor à sua proposta, ou mesmo da declaração do consumidor ter aceitado a oferta, por se tratar de declaração unilateral de vontade do fornecedor, da qual exsurge obrigação perfeita, ipso facto, exigível. (aprovada por unanimidade) e " A oferta suficientemente precisa veiculada pelo fornecedor através da Internet, implica, via de regra, contrato de adesão conclú́do com aderência virtual do consumidor, haja vista que o conteúdo contratual foi pré-elaborado de maneira abstrata, genérica, rígida e uniforme. (aprovada por unanimidade).

${ }^{60}$ LORENZETTI, Comeércio eletrónico, p. 187.

${ }^{61}$ Sobre o tema veja artigo específico de PODESTÁ, in DeLucca/Internet, p. 155 e seg.

Revista da Faculdade de Direito da UFRGS, v. 21, Março/2002 contra invasões no site ou na rede ${ }^{62}$ deveres de boa-fé específicos do meio virtual, perenização da oferta e do contrato e devere de cooperação na comunicação (o silêncio do fornecedor pode ser usual no comércio, mas é fonte de insegurança e quebra da confiança frente ao consumidor) ${ }^{63}$ na execução à distância (geralmente por correio e outros meios de execução da prestação característica , que é a do fornecedor) e no pagamento à distância (cuidados ao retirar a quantia do cartão de crédito, com o número do cartão de crédito, etc.), somados a cuidados específico aos perigos do meio virtual (criptografia combate aos hackers, arquivação múltipla para evitar perdas etc.). Nestes devere específicos de uma boa-fé atualizada às práticas (e perigos) do meio eletrônico ou virtual, destaque-se o dever de possibilita ao consumidor "perenizar" a informação ou dado eletrônico, a evitar que a confiança despertada por uma oferta, publicidade ou contrato, seja frustada com a mudança no tempo (imediata, muito fácil e sem custos no mundo virtual) das "regras do jogo", da oferta, do leilão, do contrato etc.

Os deveres de informação, de confirmação e de cuidado dos fornecedore como o de confirmação individual, de do comércio eletrônicos são preocupações de e da doutrina.${ }^{64}$ Em resumo, deve o fornecedor informar sobre o meio usado, sobre o produto ou serviço que oferece, sobre as suas condições gerais contratuais e condições específicas da oferta e deve se identificar de específicas da oferta e deve se identificar de
forma clara e eficaz. ${ }^{65} \mathrm{O}$ projeto da $\mathrm{OAB} /$ eletrônica deve conter claras e inequívocas informaçōes sobre: a) nome do ofertante, e o número de sua inscrição no cadastro geral do Ministério da Fazenda, e ainda, em se tratando de serviço sujeito a regime de profissão regulamentada, o número de inscrição no órgão fiscalizador ou regulamentador; b) identificação e endereço físico do armazenador, d) meio pelo qual é possível contatar o ofertante, inclusive correio eletrônico; e) o arquivamento do contrato eletrônico, pelo ofertante; $f$ ) instruções para arquivamento do contrato eletrônico, pelo aceitante, bem como para sua recuperação, em caso de necessidade; e g) os sistemas de segurança empregados na operação." ${ }^{66} \mathrm{O}$ projeto, muito corretamente, impõe uma série de deveres de boa-fé ao fornecedor: limitava as informações que o fornecedor podia requerer do todos os projetos de lei, do direito comparado forma clara e eficaz. ${ }^{65}$ O projeto da OAB/ endereço físico do estabelecimento; c)

${ }^{62}$ Sobre o tema veja artigo específico de SIMÃO FILHO, in DeLucca/Internet, p. 101 e seg.

${ }^{63}$ No direito geral, tanto o Art. 1084 do $\mathrm{CCBr}$.CCB/16, quanto o Art. 11 do $\mathrm{CCBr} . \mathrm{CCB} / 2002$ dispõem que: " Art. 111. O silêncio importa anuência, quando as circunstâncias ou os usos o autorizarem, e não for necessária declaração de vontade expressa." Neste, sentido, afirmo no texto que, no mundo virtual, o silecio náo significa aceitação dos consumidores e sim, abuso comercial, a violar a confiança dos consumidors frone aos profissionais, os fornecedores do comércio eletrônico. A vontade do consumidor pode ser expressa por palavras ou atos (clicks, condutas sociais típicas etc.), mas não presumida do silencio. Veja nesse sentido decisão do Tribuna de Colônia (OG Köln), de 04.09.1998, in VuR 1999, p. 69-71, que considerou abusivo a nova prática dos fornecedores cobrarem taxas de ligaçao para um consunidor que estava recebu abo uto eltrônicos, Saraiva, São Paulo, 2001, p. 20

${ }_{64}$ Veja, por todos, em síntese de Direito Comparado perfeita, LORENZETTI, Comercio eletrónico ,p. 188 a 190.

${ }^{65}$ Veja LORENZETTI, Comeércio eletrónico, p. 188.

${ }^{66}$ A íntegra do Projeto encontra-se in DeLucca/Internet, p. 495 e seg e o art. 4, p. 495 e 496

Revista da Faculdade de Direito da UFRGS, v. 21, Março/2002 
consumidor ${ }^{67}$ impõe o dever de identificar a mensagem como oferta comercial, ${ }^{68}$ dever de confirmar a aceitação por meio automático para o consumidor, ${ }^{69}$ dever de cuidado de criar um ambiente seguro para a contração eletrônica, ${ }^{70}$ e um dever de perenização das informaçõe enviadas, ${ }^{71}$ mas traz polêmicas normas especiais para consumidores e normas processuais. ${ }^{72}$ Ainda não há definição quanto ao texto final, e a solução virá por Medida Provisórias, segundo consta. De qualquer forma, destaque-se que a melhor solução foi a dada pela Diretiva 97/7/CE sobre contratação à distância, que assegura um extenso direito de informação do consumidor e sanciona eventuais falhas no cumprimento deste dever de informa

a um aumento do prazo de reflexão para o consumidor. ${ }^{73}$ A Diretiva 2000/31/CE, traz deveres de informação nos Art. 5,6 e 10 e o dever de confirmação da aceitação no Art. 11, direitos de privacidade e de não recebe produtos, no Art. 7 e regras especiais sobre a conclusão dos contratos por meio eletrônico (Art.9), como veremos a seguir. Também nos EUA, o Electronic Signatures in Global and National Commerce Act de 8 de junho de 2000 assegura direitos de informação, de disclosure dos termos do negócio e direito de reflexão ao consumidor.

Norbert Reich destaca que importante para o consumidor éo tempo da informação, o modo clareza da informação, a língua, sua identificação

${ }^{67}$ Dispunha o Art. 5 do referido projeto da OAB/SP, depois PL 1589:"Art. $5^{\circ}$ - O ofertante somente poder

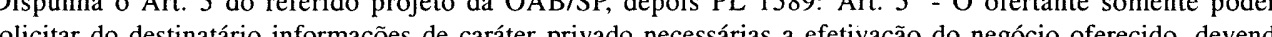
solicitar do Art 5 do $\S 1^{\circ}$ - A autoriza $\tilde{a}^{\circ}$ de que trata o caput deste artigo constará em destaque, não podendo estar vinculada 1 - A an çôes em violação ao disposto neste artigo." Veja DeLucca/Internet, p. 496 .

${ }^{68}$ Assim o texto:" Art. $8^{\circ}$ - O envio de oferta por Mensagem eletrônica, sem prévio consentimento dos destinaários, deverá permitir a estes identificá-la como tal, sem que seja necessário tomarem conhecimento de se conteúdo." Veja DeLucca/Internet, p. 496

${ }^{69}$ Assim o texto: "Art. $7^{\circ}$ - Os sistemas eletrônicos do ofertante deverão transmitir uma resposta eletrônica automática, transcrevendo a mensagem transmitida anteriormente pelo destinatário, e confirmando seu recebimento." Veja DeLucca/Internet, p. 496.

${ }^{70}$ Assim o texto: "Art. $6^{\circ}$ - A oferta pública de bens, serviços ou informações à distância deve ser realizada em ambiente seguro, devidamente certificado. "Veja DeLucca/Internet, p. 496

${ }^{71}$ Assim o texto do "Art. 13, § $2^{\circ}$ - Deverão os ofertantes, no próprio espaço que serviu para oferecimento de bens, serviços e informações, disponibilizar área específica para fins do parágrafo anterior, de fácil identificação pelos consumidores, e que permita seu armazenamento, com data de transmissão, para fins de futura comprovação." Veja DeLucca/Internet, p. 497

${ }^{72}$ Em especial a referentes à participação dos notários, veja crítica em Carvalho, p. 128 e seg. e o Art. 13, com o seguinte texto: 'Art. 13 - Aplicam-se ao comércio eletrônico as normas de defesa e proteção do consumidor.

$\S 1^{\circ}$ - Os adquirentes de bens, de serviços e informações mediante contrato eletrônico poderão se utilizar da mesma via de comunicação adotada na contratação, para efetivar notificações e intimações extrajudiciais, a fim de exercerem direito consagrado nas normas de defesa do consumidor. $\S 2^{\circ}$ - Deverão os ofertantes, no próprio espaço que serviu para oferecimento de bens, serviços e informações, disponibilizar área específica para fins do paŕarafo anterior, de fácil identificacão pelos consumidores, e que permita seu armazenamento, cora dus do

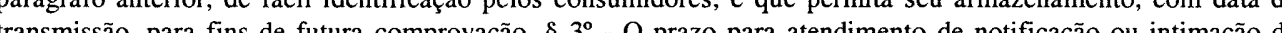

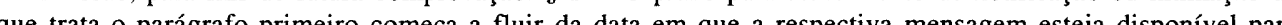
que trata o para pristo acesso pe

${ }^{73}$ Assim também MEENTS, p. 200 e REICH/NORDHAUSEN, p. 198.

Revista da Faculdade de Direito da UFRGS, v. 21, Março/2002 e sua imputabilidade ao fornecedor. ${ }^{74}$ Repita-se que, aplicando o Código de Defesa do Consumidor e as linhas gerais de boa-fé aqui especificadas, em uma visão contratual renovada, parece-me que podemos impor os mesmos deveres de conduta de boa-fé aos fornecedores no mercado eletrônico brasileiro, mesmo antes da aprovação de lei específica. ${ }^{75}$

Quanto à aceitação entre ausentes ${ }^{76}$ o CDC nada regula, assim, aplicáveis as normas subsidiárias da legislação geral. Segundo o Código Civil Brasileiro de 1916, em seu art. 1.086, e o novo Código Civil de 2002, em seu artigo $434,{ }^{77} \mathrm{o}$

${ }^{74}$ Assim REICH/NORHAUSEN, p. 187 a 193

75 Assim também concluiu SANTOLIM, p. 36 e 37, CARVALHO, Ana Paula Gambogi, Contratos via Internet, Belo Horizonte, Del Rey, 2001 p. 147 e Roberto SENISE, in DeLucca/Internet, p. 488, também DeLucca/Internet, p. 94 e seg., esclarecendo, porém, a necessidade de normas específicas. Sobre o consenso internacional da imposição da boa-fé à atuação dos fornecedores neste meio, veja LORENZETTI,, Comeércio eletrónico, p. 246 e 247. Veja o advogado da Microsoft SMITH, p. 324 ponderando os efeitos "econômicos" positivos da aplicação da boa-fé e princípios gerais de proteção dos mais fracos no comércio eletrônico : "Traditional consumer protection principles- such as the obligations to provide relevant information, engage in honest and fair practices, and respect consunmer privacy - ave generated a common understanding of commercial practices that help provide stavbility, predicability, and consumer and investors confidence. Adherence to theses principles is equally valuable online.

${ }^{76}$ Critica, com razão, esta terminologia, BARBAGALO, p. 26 e seg. Veja meu Curso/OEA e sugestão de nova CIDIP.

${ }^{77}$ Assim o texto: "Art. 434. Os contratos entre ausentes tornam-se perfeitos desde que a aceitação é expedida, exceto: I - no caso do artigo antecedente;II - se o proponente se houver comprometido a esperar resposta;III - se ela não chegar no prazo convencionado.

${ }^{78}$ Veja detalhes in CARVALHO, p. 149.

79 Veja em CARVALHO, p. 86 e 87, quais são as ofertas na Internet consideradas entre presentes (interactivas0 e quais entre ausentes (e-mail, sites etc.): "Ofertas transmitidas ao oblato por meio de Internet Relay Chat, ou
seja, de forma interativa, devem ser consideradas, como no caso de ofertas feitas por telefones, inter seja, de forma interativa, devem ser consideradas, como no caso de ofertas feitas por telefones, inter mail ou por "clique" em una homepage, hipóteses em que ocorre um lapso remporal significtivo por e-

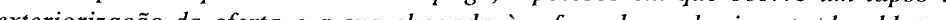

${ }^{80}$ Veja minas críticas ao livro de CARVALHO, p. 308 e 309: " Parece-me, pois, que como a autora analisou a contratação via Internet de Consumo (B2C) e entre comerciantes (B2B), sem distingui-las estritamente, faltou considerar com mais precisão a pluralidade de fontes legislativas, pois deveria ter analisado mais fortemente a influência do CDC na imposição de uma teoria da declaração atualizada, ou teoria da confiança, resultando na quase impossibilidade de extinção da oferta (Art. 30 e 35 do $\mathrm{CDC}$, este último muito pouco estudado na obra). A autora poderia também ter analisado mais profundamente as regras de direito comercial brasileiro sobre contratação comercial (em especial a compra e venda mercantil, nacional e internacional, assim como sobre interpretação da vontade comercial segundo a boa-fé, distinguido enfim com mais clareza os momentos de aplicação do $C D C$, do Código Comercial e do Código Civil como subsidiário a ambos códigos especiais. Ao leitor mais desavisado, esta concomitância na apresentação e comentário das fontes pode levar à conclusão errôneas, ou que se aplicará a nova obrigatória oferta, ex-"invitatio ad offerendum", do CDC a todo o comércio via Internet (B2B), ou que em matéria de oferta o Art. 1081 do CCBr.CCB ainda é a regra principal, ou que em matéria de contratação de consumo e comercial, nacional e internacional, via Internet estas fontes se aplicam ao mesmo caso, o que não me parece conclusão válida ou comprovada. 


\section{Interpretação dos contratos e} direito de arrependimento

A doutrina é unânime que a interpretação dos contratos do comércio eletrônico en volvendo consumidores deve ser diferenciada, sensível à proteção do contratante mais fraco $\mathrm{e}$ leigo, o consumidor. ${ }^{81} \mathrm{~A}$ interpretação se faz a seu favor (art. 47 do CDC) e o recurso ao direito subsidiário geral só se fará quando favorável ao consumidor. Assim, por exemplo, enquanto no direito civil geral a regra é que "o silêncio importa anuência, quando as circunstâncias ou os usos o autorizarem, e não for necessária a declaração de vontade expressa" (Art. 1084 do $\mathrm{CCB} / 16$ e Art. 11 do $\mathrm{CCB} / 2002$ ), no direito do consumidor a regra é inversa: o silêncio do consumidor significa negação e indício que aconteceu uma prática abusiva do fornecedor. ${ }^{82}$ Aqui incluem-se as práticas de envio de produtos e serviços não solicitados. Neste sentido, pode-se afirmar que, no mundo virtual, o silêncio não significa aceitação dos consumidores e sim indício de que um ato comercial dos fornecedores pode ser abusivo,

a violar a confiança dos consumidores frente aos profissionais, os fornecedores do comércio eletrônico. A vontade do consumidor neste meio pode ser expressa por palavras ou atos (tocar símbolos, ícones, fazer clicks - point and click agreements, click-wrap agreements -e condutas sociais típicas, etc.), mas não presumida do silêncio. ${ }^{83}$ Aqui há também que se considerar as linhas de presunção da identidade do agente contratante, tanto fornecedor, como consumidor, onde as atuais linhas de boa-fé impõem aplicação das teorias da aparência (para o profissional, já que se aplica o Direito Comercial) e da confiança (para o consumidor-leigo).$^{84}$ Dentre os contratos que merecem um interpretação especial estão os que envolvem jogos de azar, prêmios, conteúdos pornográficos e de lazer, geralmente envolvendo a ordem pública dos países conectados. ${ }^{85}$

A doutrina é unânime que aos contratos à distância do comércio eletrônico se aplica 0 Art. 49 do CDC e o prazo de reflexão de 7 dias. ${ }^{86}$ A doutrina ainda cuida da forma da contratação

${ }^{81}$ Assim diferenciam o comércio B2B do B2C: VIVANT, p. 173, FÉRAL-SCHUHL, p. 147 e seg., LORENZETTI Comeércio Eletrónico, p. 218 e seg. , BRIZZIO, p. 42, MAYER/Partie Faible, p. 514 e seg., MEENTSz, p. 179 e seg., REICH/NORDHAUSEN, p. 2 e seg., Köhler/Arndt, p. 35 e seg., HARTING, p. 67 e seg., no Brasil, SANTOLIM, p. 37 e seg. , SANTOS e ROSSI, p. 118 e seg., DELUCCA/Internet, p. 89, e seg., SIMÃO, p. 10 e seg., PODESTÁ, p. 162 e seg., LUCON, p. 354 e seg., SENISE, p. 488, LOTUFFO, p. 222, GRECO, Marco Aurélio, Direito e Internet, Ed. Dialética, São Paulo, 2000, p. 49 e seg e LUCON, Rodrigo, "A Internet e as relações de consumo", in Internet: o direito na era virtual, Schoueri, Luis Eduardo (Org.), Rio de Janeiro: Forense, 2001,p. 3

${ }^{82}$ Assim, por exemplo, se o consumidor recebe um produto que não pediu e mantêm o seu "silêncio", o direito positivo brasileiro atual (Art. 39 do $C D C$ ) não pressupõe que sua passividade seja aceitação, ao contrário, pune o fornecedor, afirmando que o produto (por exemplo, livros ou cartao de crédito enviado sem requisiçẫo pelo CDC (Art. 39, III c/c \& único)

${ }^{83}$ Assim afirmou Clóvis do Couto e Silva, Obrigação como Processo, Bushasky, Sao Paulo, 1972, p. 26: "É manifesto, assim, que a autonomia da vontade e a teoria das fontes das obrigações, que com ela se vincula, se encontram em período de transformação e de reelaboração dogmática. De um lado, a intervenção estatal, de outro, a tipificação social, e sobretudo os atos jurídicos de caráter existencial, forçaram a revisão dos conceitos."

${ }^{84}$ Sobre o tema, veja magistral, LORENZETTI, Comeércio eletrónico, p. 219 e seg e , no Brasil, GREGO, p. 30 e seg.

${ }^{85}$ Sobre o tema, veja WIMMER/MICHAEL, p. 40 e seg.

${ }^{86}$ Veja, por todos, BENEVIDES DE CARVALHO, p. 104 a 106.

Revista da Faculdade de Direito da UFRGS, v. 21, Março/2002 eletrônica, concluindo que o contrato é por escrito e há a qualidade de documento ao documento eletrônico, ${ }^{87}$ do lugar da contratação (tema bastante polêmico, se aplicáveis as normas de Direito Internacional Privado, como veremos a seguir), ${ }^{88} \mathrm{da}$ assinatura eletrônica, ${ }^{89}$ da eficácia probatória dos documentos eletrônicos, ${ }^{90}$ da responsabilidade dos intermediários e do organizador da cadeia de fornecimento pela Internet ${ }^{91}$ e das garantias no comércio eletrônico. Aqui, parece-me, mais importante, com a crescente internacionalização das relações de consumo na Internet, tratar da le aplicável a esta contratação, pois é esta le aplicável que estabelecerá os limites e regras para a proteção do sujeito mais fraco, o consumidor, neste meio tão fluído, que é eletrônico. Como asseverou o mestre da UFRGS Clóvis do Couto e Silva,: "A liberdade absoluta de contratar, sem legislação marginal ao mercado, que harmonizasse as forças econômicas em litígio, ocasionou, nos países altamente industrializados, profunda. restriçôes ao princípio da autonomia da vontade. Os particulares se viam não só forçados a não poder escolher com quem contratar - 'Organizationzwang' - como igualmente se lhes impossibilitava o diálogo

a respeito do conteúdo do contrato. $" 92$. Em outras palavras, se o meio virtual, a rede da Internet e a globalização aumentam a liberdade teórica dos consumidores, a prática lhes limita e a solução só pode ser a regulamentação pelo Direito.

\section{Disciplina no Direito Internacional Privado}

Apesar dos contratos de comércio eletrônico entre fornecedores (nacionais estrangeiros) e consumidores representarem, hoje, apenas cerca de $25 \%$ do chamado ebussiness internacional, pois $85 \%$ seriam relações entre comerciantes, ${ }^{93}$ pode se constatar uma certa desproteção do consumidor e de seus interesses específicos nas Convenções Internacionais já assinadas e um certo despreparo do direito brasileiro para fazer frente a este fenômeno crescente mundial do comércio eletrônico de consumo. ${ }^{94}$ A posição do consumidor nesta nova realidade contratual é cada vez mais fraca ou vulnerável e 0 desequilíbrio das relações de consumo é intrínseco, ${ }^{95}$ dai a necessidade de uma efetiva

${ }^{87}$ Assim MEENTS, p. 51 e seg.

${ }^{88}$ Trataremos do tema em detalhes a seguir, mas veja, com opiniões contrárias, BARBAGALO, p. 77 e seg.

${ }^{89}$ Sobre o tema veja livro específico de Davi Monteiro DINIZ, Davi Monteiro, Documentos Eletrônicos, Assinaturas Digitais, LTr, São Paulo, 1999.p. 11 e seg.

${ }^{90}$ Veja CARVALHO, p. 150 a 152.

${ }^{91}$ Veja minha rescensão ao livro de Carvalho, in RDC 40, p. 309 e 310

${ }^{92}$ Clóvis V. do Couto e Silva Silva,- A Obrigação como Processo - editora Bushatsky, pg. 25.

${ }^{93}$ CARVALHO, p. 20 esclarece que na América Latina, em 2000, já existiam 8,12 milhôes de Internautas e Brasil, 4,25milhões, com previsão que este número em 2003 cresça para mais de 10 milhões.

${ }^{4}$ Esta foram as conclusões de meu curso na OEA, resumido no artigo na RT 788/11, onde sugiro uma CIDIP para proteção dos consumidores turistas e no comércio eletrônico, veja CIDIP, p. 11 e seg. ${ }^{95}$ CALAIS-AULOY, Jean, Droit de la Consommation, 3.ed., Dalloz, Paris, "Droit de la Consommation", 3.ed,Paris, Dalloz, 1992 1992, p. 1, considera que este desequillbrio sempre existiu, apenas agora está qualificado de tal

forma que é um dos objetivos sociais de nosso tempo, proteger ao consumidor em posição estruturalmente mais fraca. 
tutela através da intervenção dos Estados na elaboração de novas normas e aplicação eficaz das existentes. ${ }^{96}$

Neste sentido cabe agora, ainda que rapidamente, analisar as normas atuais de Direito Internacional Privado sobre a lei aplicável a estes contratos do comércio eletrônico, no caso da prestação ser internacional ou estar presente algum elemento de estraneidade, contratos celebrados por meio eletrônico entre consumidores residentes no Brasil e fornecedores com sede ou outro tipo de localização (sites, residência habitual, etc.) no exterior .

\section{A. As especificidades do con- sumo internacional e a neces- sidade de proteção especial do contratante mais fraco}

\section{As especifidades do consumo "internacional"}

Peço vênia para repetir aqui as observações sobre as especificidade do consumo internacional já feitas em artigo publicado, sugerindo a elaboração de uma Conferência Interamericana, de forma a fundamentar a necessidade que o Direito Internacional Privado do século XXI tem de preocupar-se e proteger de forma especial (e material) o contratante mais fraco:

"Há grande especificidade nas relações jurídicas internacionais, que se de consumo, pressupõe o diálogo entre o Direito do Consumidor e as normas (e princípios) do Direito Internacional Privado. As normas brasileiras de Direito Internacional Privado (aqui denominado DIPr.) são antigas, de $1942,{ }^{97}$ os projetos de leis existentes não prosperaram ${ }^{98}$ e a única atualização veio através das Conferências Interamericanas de Direito Internacional Privado (CIDIPs), organizadas no seio da OEA. As CIDIPs, porém, nenhuma conexão mais favorável impuseram especificamente sobre a proteção do consumidor. Note-se, também, que as normas nacionais, reguladoras do comércio internacional (por exemplo, o novo $\mathrm{CCB} / 2002$ que regula a empresa estrangeira em atuação no Brasil), assim como direito uniforme do comércio internacional (por exemplo, a Convenção de

${ }^{\%}$ Assim me manifestei in El Código Brasileño de defensa del consumidor y el Mercosur, in GHERSI, Carlo Alberto (Director), Mercosur-Perspectivas desde el derecho privado, Editorial Universidad, Buenos Aires, 1996, El Código brasileño, p. 199 , também BOTANA GARCÍA, Gema e RUIZ MUNOZ, Miguel (Coord.), Curso sobre protección jurídica de los consumidores, Ed. Ciencias Juridicas, Madri, 1999, , p. 8 menciona a atual "degradación de la posición del consumidor"

${ }^{97}$ A atual LICC é do tempo de Vargas e da Segunda Guerra Mundial, Decreto-Lei 4.657 de 4 de setembro de 1942.Exceção feita aos EUA, ao Quebéc e à Venezuela, os outros países da américa Latina também sofrem dos mesmos problemas de desatualizac̃a, veja PARRA-ARANGUREN, Gonzalo, Curso general de Derecho Internacional Privado- Problemas Selectos, Fundación Fernando Parra Aranguren, Caracas, 1991, pert e seg.

${ }^{{ }^{8}}$ Sem mencionar os projetos antigos, de Haroldo Valladão e outros, os projetos hoje existentes no tema, como o projeto da OAB-SP sobre comércio eletrônico ou o projeto de nova LICC de Jacob Dolinger e João Grandino Rodas, ou visam apenas atualizar os aspectos materiais do novo consumo internacional ou foram retirados do Parlamento e não mais tramitam, deixando sem regular de forma especial o problema da lei aplicável a estes cada vez mais comuns contratos internacionais de consumo. O novo CCBr.CCB/2002 não vem acompanhado de uma nova LICC. Outro bom exemplo é que dos 80 PLs apensados ao Projeto de Lei 1825/91 de atualização do CDC, apenas três (PL 884/95, PL 2646/96 e PL 2893/97) tratam de temas de consumo internacional e isto no que se refere à informação prestada ao consumidor, tema já tratado pelo Art. 31 do CDC.

Revista da Faculdade de Direito da UFRGS, v. 21, Março/2002
Viena sobre Compra e Venda) ${ }^{99}$ ou a denominada lex mercatoria (por exemplo, a tão falada Lei Modelo da UNCITRAL sobre comércio eletrônico), ${ }^{100}$ geralmente não se preocupam em proteger o consumidor, ${ }^{101}$ ao contrário tentam excluir estes contratos de seu campo de aplicação.

Na Europa, desde a década de 1970, os doutrinadores propugnam a necessidade do Direito Internacional Privado voltar-se para a proteção dos mais fracos, especialmente dos consumidores, ${ }^{102}$ incluindo novos elementos de conexão mais flexíveis e adaptados à tutela do

vulnerável nestas situações privadas internacionais, face a falência das ditas conexões "neutras" e rígidas, mais adaptáveis ao relacionamento entre iguais ou pelo menos entre profissionais, comerciantes. ${ }^{103}$ No Brasil, as normas de conflitos de leis no espaço, que indicam a lei aplicável a um contrato do comércio eletrônico entre um consumidor residente no Brasil e um fornecedor com residência (sede) no exterior, encontram-se na LICC/42, são rígidas e antigas, e nada mencionam sobre consumidor (sujeito de direitos desconhecido à época), nem sobre a proteção do contratante mais fraco ou vulnerável. ${ }^{104}$ Tal situação exige uma mudança e

O exemplo mais importante são as normas uniformizadoras da Convenção da ONU sobre Compra e Venda de Mercadorias de 1980, conhecida como Convenção de Viena de 1980, que em seu Art. 2, a e e Art. 5, procuram evitar Mercadorias de 1980, conhecida como Convenção de Viena de 1980 , que em seu Art. 2, a e Art. 5, procuram evita a aplicação destas normas do comércio internacional aos contratos com consumidores-leigos. Veja sobre ót o tem Montevidéo, 1998, p. 506 e GARRO, Alejandro Miguel e ZUPPI, Alberto Luis, Compraventa internacional de mercaderías, Ed. La Rocca, Buenos Aires, 1990, p. 81 . O Art. $2^{\circ}$ da Convenção de Viena de 1980 dispõe: "Esta mercaderias, Ed. La Rocca, Buenos Aires, 1990, p. 81 . O Art. 2 da Convençao de Viena de 1980 dispoe. "Esta convenção não se aplica às vendas. a) de mercadorias adquiridas para uso pessoal, familiar ou domestico, salvo se o vendedor, antes ou no momento da celebraşão do contrato, não soubesse nem devesse saber que as mercado-
rias eram adquiridas para tal uso".

${ }^{100}$ Como mencionamos anteriormente, aA lei modelo da UNCITRAL (que efetivamente se dedica ao comércio internacional) versando sobre comércio eletrônico expressamente informa não afastar as normas tutelares e parece querer excluir os contratos de consumo através de meios informáticos de seu campo de aplicação com o texto: "Art. 1. Ámbito de aplicación - La presente Ley* será aplicable a todo tipo de información en forma de mesaje de datos utilizada en el contexto de actividades comerciales. ${ }^{*}$ La presente ley no deroga ninguna norma jurídica destinada a la protección del consumidor."

${ }^{101}$ Assim BOTANA, p. 21, citando os princípios de UNIDROIT sobre os contratos comerciais internacionais e a Convenção de Viena sobre compra e venda internacional de mercadorias de 1980.

${ }^{102}$ Ficaram famosos os trabalhos de ZWEIGERT, NEUHAUS e LANDO, sugerindo o primeiro que o DIPr. incluisse

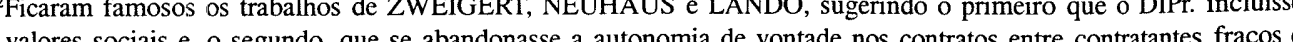
fortes como os de consume o domicílio do contratante mais fraco, veja também o estudo de VON HOFFMANN Bernd, Über den Schutz des Schächeren bei internationalen Schuldvertragen, in RabelsZ 38 (1974), Bernd von, Über den Schutz des Schächeren Schächeren bei internatonalen Schen in RabelsZ 38 (1974), (396-420) 398 e seg. e de KROPHOLLER, Jan, Das bei internationalen Schuldvertragen, in RabelsZ 38 (1974), ( $396-420)$, p. 398 e seg. e de KROPHOLLER, Jan, Da ${ }^{103}$ Assim KROPHOLLER, 1978, p. 636

${ }^{104}$ Sobre a necessária proteção do sujeito mais fraco também em Direito Internacional Privado, veja MAYER, Pierre in GHESTIN, Jacques e FONTAINE, Marcel, La protection de la partie faible dans le rapports contractuelsComparaison Franco-Belges, Paris, L.G.D.J., 1996, p. 513 e seg., e os clássicos alemães VON HOFFMANN, Bernd von, Über den Schutz des Schächeren bei internationalen Schuldvertragen, in RabelsZ 38 (1974), ( $396-$ 420), p. 398 e seg. e KROPHOLLER, Jan, Das Kollisionsrechtliche System des Schutzes der Schwächeren Vertragspartei, in RabelsZ 42 (1978), (634-661), p. 634 e seg., assim como os mais recentes artigos, JUNKER, Abbo, Von Citoyen zum Consommateur-Entwicklung des internationalen Verbraucherschutzrechts, in IPRAX 1998, p. 67 e seg., e TONIOLLO, Javier Alberto, La protección internacional del consumidor- Reflexiones desde la perspectiva del Derecho Internacional Privado Argentino, in Revista de Derecho del Mercosur, ano 2, nr. 6 diciembre de 1998, Javier Alberto, La protección internacional del consunidor-Reflexiones desde la perspectiva del Derecho Intermacional Privado Argentino, in Revista de Derecho del Mercosur, ano 2, nr. 6, diciembre de 1998, p. 96. 
uma nova interpretação do Direito Internacional Privado pátrio. O consumo internacional tem especificidades que não se pode negar.

Ao sugerir a elaboração de novas regras sobre a proteção internacional do consumidor, procurei estabelecer as especificidades das relações de consumo internacionais, se comparadas às relações comerciais internacionais, objeto da normas hoje existentes, ${ }^{105}$ observações que me parece interessante de reproduzir aqui. Assim, se no comércio internacional também há a barreir da língua, a barreira da falta de informações, a normas e costumes diferentes, as dificuldades e a insegurança na entrega e no pagamento, as dificuldades na garantia, no nível qualidade e no serviço pós-venda, certo é que estas dificuldades qualificam-se quando o parceiro contratual é um leigo, um consumidor. ${ }^{106}$

A primeira das especificidades do consumo internacional é , pois, o desequilíbrio intrínseco informativo e de especialização entre os parceiros contratuais internacionais face ao status leigo e vulnerável do parceiro-consumidor. O comércio internacional, as relações de compra venda ou de prestação de serviços entre pessoas com sede em países diferentes, geralmente ocorre entre pessoas jurídicas ou profissionais, comerciantes e empresários, logo, especialistas e profissionais para poderem se movimentar no cenário dos negócios internacionais. No consumo internacional não é esta a realidade. O parceiroconsumidor é atraído ou por métodos agressivo ${ }_{105}$ Sobre as dificuldades do comércio internacional veja FELDSTEIN DE CÁRDENAS, Sara , Contratos Internacionais, Abeledo-Perrot, Buenos Aires, 1995, p. 60 e seg. e MOURA RAMOS, Rui Manuel, e SOARES, Maria especificidade mesmo a nternacionais, Almedina, Coimbra, 1986, p. 9 e seg. Chega-se a advogar, pela sua Robert, Droit du Commerce International, Dalloz, Paris, 1991, p. 1.

${ }^{106}$ Assim Comissão Européia, Guía del consumidor europeo en el mercado único, Comisión Europea, Bruxelas, 1995 , p. 15 e 16

${ }^{107}$ Neste sentido destaque a decisão do STF não considerando "consumo" relações de importação de matéria prima entre dois comerciantes, SENTENÇA ESTRANGEIRA CONTESTADA $\mathbf{N}^{\circ}$ 5.847-1, Acórdão promulgado em 01.12.1999, Rel. Min. Mauricio Corrêa. Veja meus comentários a esta decisão do STF, junto com $36 / 221$ e seg.

${ }^{108}$ Rara exceção seria o contrato de time-sharing ou multipropriedade, que é uma relação duradora, se bem que flúda, por vezes nacional ou internacional (com círculos de trocas), veja sobre assunto TEPEDINO,Multipropriedade e meu artigo, in Revista Direito do Consumidor, São Paulo, vol 22 (1997), pg. 64-86.

Revista da Faculdade de Direito da UFRGS, v. 21, Março/2002 fenômeno pontual e sazonal, comprar à distância de um fornecedor da Califórnia (EUA) um determinado soft ware ou livro também é um fenômeno eventual e descontínuo. As regras do comércio internacional, as regras de direito internacional privado, em geral, estão construídas sobre a base da confiança e da continuidade, do crescer de relações: aquele que compra internacionalmente, voltará a compra se a "execução" for adequada, há que se proteger aquele que vende, aquele que envia sem muitas garantias e sem conhecer seu cliente propriedade sua para país distante. No consumo internacional, a prioridade se inverte, o comprador não é um comerciante, não é expert é ao contrário leigo, compra pelo preço, pelas qualidades apregoadas, confia em uma muitas vezes inexistente proteção legal e asşume enormes riscos ao viabilizar o número dè seu cartão de crédito.

As outras especificidades são o pequeno valor, a massificação e a difícil reexecução. O consumo internacional é hoje um fenômeno de massas, basta pensar o turismo sazonal, o time-sharing, com seus círculos de trocas internacionais, os pacotes turísticos par grandes festas, os transportes aéreos, os cruzeiros marítimos etc. ${ }^{109}$ Individualmente considerado o contrato internacional de consumo tem , porém, pequeno valor, seja para a economia de um país ou de um fornecedor. Este pequeno valor dificulta em muito o acesso à justiça, faz com que a lide fique reprimida, dificulta que o consumidor assuma gasto exagerados, seja para reclamar, para procura novamente o fornecedor, para fazer valer sua

arantia etc. O consumo internacional ainda possui uma última especificidade, que lhe é comum com os serviços em geral, sua reexecução, em caso de frustração das expectativas do contratante consumidor é bastante dificultosa. Em caso de turismo, reeditar algo, uma excursão, dias de férias em praia poluída, recuperar o conforto de um hotel em país distante e assim por diante, é tarefa quase impossível. Em matéria de contratos à distância, a eventualidade da perda de tempo, da perda de uma chance e de acontecerem danos morais anexos à má-execução do contrato internacional de consumo também são quase uma constante, o melhor é prevenir os danos e minimizá-los, ou a resposta será apenas econômica, com as perdas e danos respectivas.

Destaque-se, por fim, que há um forte componente político-econômico nas regras de proteção nacional e internacional dos consumidores, pois se um país exportador mantém um alto nível de proteção de seus consumidores aumenta a qualidade de seus produtos, que encontrarão maior aceitação internacional (por exemplo, a Alemanha). Se um país turístico, aumenta o grau de proteção dos turistas e facilita o seu acesso à Justiça, garante melhores condições ao turismo e facilita o desenvolvimento deste importante setor econômico. em outras palavras, regras sobre o direito do consumidor interessam a competitividade do mercado interno e a competitividade internacional, assim como contribuem à̀ criação de um mercado interno com concorrência leal e à realização das políticas governamentais. ${ }^{110}$

${ }^{109}$ A doutrina européia alerta desde a década de 80 e, especialmente na década de 90 , que o turismo de massa é un dos setores econômicos que mais cresce na União Européia e que a defesa do consumidor se faz necessária até mesmo como instrumento harmonizador da concorrência, veja, por todos, com estatísticas sobre o crescimento do setor turístico, LETE ACHIRICA, Javier, El Contrato de Multipropr consumidores, Ed. Cedec, Barcelona, 1997, p. 32 a 34.

${ }^{110}$ Assim também GHERSI, in: Mercosur - Perspectivas desde el derecho privado II, p. 30 e seg.

Revista da Faculdade de Direito da UFRGS, v. 21, Março/2002 
2. Exame do Art. $9^{\circ}$ da $\mathrm{LICC} / 42$ e a necessidade de evoluir o Direito Internacional Privado para a proteção do contratante mais fraco

De qualquer maneira, face à multiplicidade de opiniões da doutrina uma análise das normas positivas do Direito Internacional Privado se impõe. Segundo a vigente LICC, aplicável neste caso seria a lex loci celebrationis (Art. 9 caput da LICC/42: "Para qualificar e reger as obrigações, aplicar-se-á a lei do país em que se constituírem"). A norma do Art. $9 \S 1$ LICC/42 impõe uma aplicação cumulativa de lei brasileira quanto à forma, em caso de execução no Brasil. Importante é a norma do Art. $9 \$ 2 \mathrm{da} \mathrm{LICC/42,}$ que é usada para identificar o lugar da proposta em contratos entre ausentes ou em contratos à distância, como a maioria dos contratos internacionais de consumo nos dias de hoje. Segundo o $\$ 2$ do Art. 9, "a obrigação resultante do contrato reputa-se constituída no lugar onde residir o proponente". A interpretação desta norma se faz pela lex for (lei brasileira). Como em matéria de consumo, a lei brasileira material determina que o proponente é sempre o fornecedor (art. 30 CDC) teríamos sempre, se usado o Art. $9 \$ 2^{\circ}$ da LICC 42), a aplicação da lei do lugar de residência do fornecedor para reger os contratos à distância mesmo os de consumo, como os contratos do comércio eletrônico de consumo. ${ }^{111}$ Observar-

se-ia, pois, uma forte incoerência do Direito Internacional Privado brasileiro, que ao invés de proteger o sujeito constitucionalmente identificado e seus direitos fundamen 5,XXXII da $\mathrm{CF} / 88$ ), privilegiaria o fornecedor com sede no exterior.

Neste sentido, repita-se aqui o que ensina KROPHOLLER, ${ }^{112}$ que é necessário elaborar normas específicas de DIPr. para proteção dos consumidores leigos ou não profissionais, pois as conexões hoje existente para regular o comércio internacional todas tem como base o equilíbrio estrutural de forças ou de interesses profissionais entre os agentes (ambos profissionais) envolvidos, como conexões da autonomia da vontade (escolha da lei que regerá o contrato pelas partes, no contrato ou após), o local da execução (geralmente o local de execução da prestação característica, sempre prestada pelo profissional em caso de contrato de consumo internacional), ou do local de conclusão do contrato conectando o contrato com a ordem jurídica do país do ofertante, em contratos à distância, sempre também o ofertante).

Este equilíbrio estrutural inexiste nos contratos internacionais concluídos com consumidores leigos. Assim, se a autonomia de vontade das partes é hoje considerada o mais importante elemento de conexão no comércio internacional, ${ }^{113}$ encontra ela um limite no que se refere às relações de consumo. Como ensina NEUHAUS, a possibilidade de escolha da lei pelas partes, a autonomia da vontade em DIPr.,

${ }^{111}$ Já em matéria de acidentes com produtos e serviços defeituosos, como a regra aplicável também é a do Art. 9 , agora interpretada como lex loci delicti, a lei do lugar em que foi cometido o ato ilícito ou lei do lugar em que aconteceu o dano e seus consequências, no caso o mercado brasileiro, onde reside a vítima do produto ou serviço LICC/42). Veja MARQUES, Claudia Litranico, é que aplicarı́amos a lei brasileira (Art. 17 CDC c/c Art. 9 cICC/42). Veja MARQUES, Claudia Lima, Novos rumos do Direito Internacional Privado quanto às obrigaçoes resultantes de atos ilícitos (em especial de acidentes de trânsito), in Revista dos Tribunais, São Paulo, vol. ${ }^{112}$ KROPHOLLER, p. $398 \mathrm{e}$ seg.

${ }^{113} \mathrm{DE}$ BOER, Ted. M., Facultative Choice of Law - The procedural status of choice-of-law rules and foreign Law, Recueil des Cours, 1996, t. 257, Nijhoff, The Hague, 1997,p. 300 .

Revista da Faculdade de Direito da UFRGS, v. 21, Março/2002 perde seu sentido, se passa a ser instrumento de domínio dos mais fracos pelos mais fortes. ${ }^{114}$ Examinando a Convenção de Haia e a CIDIP IV o mestre argentino $\mathrm{BOGGIANO}^{115}$ propôs para a proteção dos consumidores uma regra de limitada autonomia: a escolha das partes só prevaleceria se fosse esta a melhor lei , a le mais favorável para o consumidor, devendo em caso contrário, aplicar-se a lei do domicílio do consumidor. Prevaleceriam como limites gerais à autonomia de vontade as normas de ordem pública internacional e as normas de polícia (Art. 1208 CCArg.). ${ }^{116}$

Segundo bem relembra JAYME, momento atual é de prevalência de normas materiais em casos internacionais., ${ }^{117}$ tempos de uma maior possibilidade de determinação própria pelo indivíduo (Selbstbestimmung.) em direito material, ${ }^{118}$ de novas técnicas nas Convenções Internacionais tentando harmo-

nizar as diferenças culturais e de desenvolvimento através da cooperação judicial e respeito às normas imperativas locais, ${ }^{119}$ tentando respeitar os direitos humanos envolvidos no caso, ${ }^{120}$ o que significa, face a revolução tecnológica atual, uma nova prevalência pela residência habitual do consumidor como novo elemento de conexão para determinar a lei aplicável ao comércio eletrônico Business-to-Consumer e novo critério para determinar a competência do foro. ${ }^{121}$ Aqui está, segundo o grande mestre de Heidelberg, o futuro do DIPr.

Como afirma KROPHOLLER, em seu famoso artigo de 1978 sobre a proteção da parte mais fraca através do Direito Internacional Privado, ${ }^{122}$ é necessário evoluir para um DIPr. impregnado de valores sociais. Também JAYME $^{123}$ ensina que as novas normas de DIPr. de proteção do consumidor, pelo menos as

${ }^{114}$ No original: "Die Parteiautonomie verliert ihren Sinn - ebenso wie die materiellrechtliche Vertragsfreiheit-, 1962, p. 172 apud von HOFFMANN, p. 396.

${ }^{115}$ Veja , por todos, BOGGIANO, Antonio,em seu texto The Contribuition The Contribution of the Hague Conference to the Development of Private International Law in Latin America. Universality and genius loci, Recueil des Cours, 1992, It t. 233, Nijhoff, Dordrecht, 1993, p. 138 e 139 .

${ }^{116 B O G G I A N O}$, The Contribuition, p. 137

${ }^{117}$ Assim JAYME, Erik, Zum Jahrtausendwechsel: Das Kollisionsrecht zwischen Postmoderne und Futurismus, in IPRAX-Praxis des Internationalen Privat- und Verfahrensrechts, 2000, p. 169, relembra que as primeiras normas comunitárias européias eram todas voltada para a jurisdição, assim também a Convenção de Bruxelas II, que trata de Direito de Família, mas que este método é insuficiente para evitar a grande importância das normas que trata de Direito de Família, mas que este método e insuficiente para evitar a grande importância das normas
materiais, muitas delas de aplicą̧ão imediata em qualquer foro, e os novos métodos alternativos de solução de controvérias, muitas vezes extra- jurisdicionais e cada vez mais freqüentes.

${ }^{118}$ JAYME, IPRAX 2000, p. 170

${ }^{119}$ Assim JAYME, IPRAX 2000, p. 168

${ }^{120}$ Assim JAYME, IPRAX 2000, p. 171, citando os casos de decisão judicial na Alemanha sobre o desastre de Tschernobyl, em que o "local do delito" foi considerado o territorio alemão onde a "nuvem radiotiva" causou danos, que devem ser indenizados pela empresa russa e, tambem, os casos sobre comércio eletrônico, em que estão sendo considerados competentes os foros do local de "distribuição" da informação por Internet, logo, do local onde está o consumidor.

${ }^{121}$ JAYME , IPRAx 2000, p. 171

${ }^{122}$ KROPHOLLER, p. 655.

${ }^{123}$ Assim manifestou-se sobre o fim material das normas de DIPr. oriundas da União Européia, JAYME (in HOMMELHOFF/JAYME/MANGOLD (Ed.), Binnermarkt-Internationales Privatrecht und Rechtsvergleichung (1995), p.35), apud JUNKER, p. 74, nota 132 .

Revista da Faculdade de Direito da UFRGS, v. 21, Março/2002 
oriundas da União Européia têm finalidade material. Sendo assim, parece-me perfeitamente razoável que as conexões escolhidas pelo DIPr. brasileiro para proteger o consumidor da região tenham como finalidade a proteção da parte mai fraca (von HOFFMAN), de seus direitos fundamentais (JAYME) e a justiça substancia no caso concreto (ZWEIGERT). ${ }^{124}$ Note-se que também em matéria de concorrência leal houve uma clara evolução em DIPr. As normas nacionais protetoras de concorrência lea atingiram forte grau de extraterritorialidade. ${ }^{125}$

Assim, concluo que, no caso brasileiro, a melhor conexão rígida seria a do domicílio entendido como residência habitual, a exemplo do Art. 3 do Protocolo de Santa Maria (Mercosul) ${ }^{126}$ ou da tradição das CIDIPs ${ }^{127}$ suas normas materiais uniformes. ${ }^{128}$ Melho ainda seria elaborar uma norma flexível, indicando a lei do domicílio do consumidor (analogicamente ao Art. 101 do CDC) como aplicável, mas permitindo ao juiz aplicar a lei

escolhida (limitadamente) pelas partes no contrato, caso esta seja mais favorável ao consumidor. ${ }^{129}$

Elaborar uma norma específica evitaria que a jurisprudência considerasse todo o $\mathrm{CDC}$ como norma de aplicação imediata, como

\section{B) As normas contratuais do CDC como normas de apli- cação imediata}

\section{A caracterização das normas de} proteção contratual à distância do CDC como normas de aplicação imediata

Estabelecida a necessidade de uma visão renovada dos princípios do DIPr. em

${ }^{124}$ Assim concorda TONIOLLO, p. 99 citando De Vischer.

${ }^{125}$ Assim conclui, examinando o $§ 98,2,1$ GWB alemã, MARTINEK, Michael, Das internationale Kartellprivatrecht Verlag Recht und Wirtschaft, Heidelberg, 1987, p.94.

${ }^{126}$ ARAÚJO, Nádia, MARQUES, Frederico Magalhães e REIS, Márcio, Código do Mercosul- Tratados e Legislação, Ed. Renovar, Rio de Janeiro, 1998, p. 161

${ }^{127}$ Segundo SIQUEIROS, José Luis, Contribucion de las CIDIP-I, II y III al Desarrollo del Dercho Internacional Privado, XIII Curso de Derecho Internacional, Secretaria General,OEA,1987, p. 170 esta foi uma das grandes Co habitual em voga na Europa, veja também CIDIP-II-1979- Convenção sobre o domicílio das pessoas físicas.

${ }^{128}$ Como ensina OPPERTI BADAN, Estado Actual del Derecho International Privado en el Sistema Interamericano IX Curso de Derecho Internacional, vol. I, Secretaria General,OEA,1983, nr. 2.7, a principal inovação da CIDIP-II sobre domićilio das pessoas físicas de 1979 foi a utilização de normas materiais uniformes. Segundo ALMEIDA, Ricardo Ramalho, A convenção Interamericana sobre domicílio das pessoas fisicas em direito internacional privado, in CASELLA, Paulo Borba e ARAUJO, Nádia (Coord.), Integração Jurídica Interamericana- As Convenções Interamericanas de Direito Internacional Privado(CIDIPs) e o Direito Brasileiro, Ltr, São Paulo, 1998, as normas da referida CIDIP-II não são "substanciais", mas sim "qualificadoras", p 217, ocorre que, na tradição germânica (veja KROPHOLLER, p. 80, KEGEL, IPR, 35, STEINDORF, Erns Sachnormen im internationalen Privatrecht, Vittorio Klostermann, Frankfurt am Main, 1958, p. 30), as normas materiais de ajuda (Hilfsnormen), são consideradas normas materiais de DIPr (materielles Sonderrecht) logo, concordamos com a opinião do mestre uruguaio OPPERTI, Curso OEA, nr. 2.7

${ }^{29}$ Assim redigi minha sugestão no artigo CIDIP: “ Art. 2 - Proteção contratual geral- 1. Os contratos e as transações envolvendo consumidores, especialmente os contratados à distância, por meios eletrônicos, de telecomunicações ou por telefone, estando o consumidor em seu país de domichio, serão regidos pela lei deste país ou pela lei mais favorável ao consumidor, escolhida entre as partes, se lei do lugar da celebração do contrato, lei do lugar da execução do contrato, da prestação característica ou lei do domicílio ou sede do fornecedor de produtos e serviços."

Revista da Faculdade de Direito da UFRGS, v. 21, Março/2002 veremos a seguir. matéria de consumo internacional e as especificades deste crescente fenômeno, vejamos, agora, a situação do direito positivado brasileiro quanto à contratação à distância no comércio eletrônico, tanto na LICC de 1942 , quanto no Código de Defesa do Consumidor, considerado como lei de aplicação imediata.

Apesar de parte da doutrina sobre comércio eletrônico ${ }^{130}$ mencionar que a regra nestes contratos seria a da autonomia da vontade, isto é, da possibilidade do fornecedor estrangeiro escolher a lei aplicável ao contrato (geralmente a de seu país sede) e incluir nas condições gerais contratuais ou no contrato de adesão oferecido na rede, tal interpretação da LICC não é majoritária ou existente na prática dos contratos de consumo (a não ser em caso de fuga do foro brasileiro, quando a disputa solucionada em outro foro, justamente para fugi da aplicação das normas de DIPr. brasileiras, em um fenômeno conhecido como forum shopping). Em outras, palavras, segundo a DIPr., ${ }^{131}$ as normas da LICC são obrigatórias (leis federais) e aplicável é o Art. $9^{\circ}$ da LICC, a excluir a autonomia da vontade nos contratos internacionais em geral, quanto mais os de consumo. há que se considerar que o DIPr. brasileiro atualizou seus princípios, assim, tratando-se de direito humano reconhecidos como direito fundamental pela Constituição Federal de 1988 (Art. 5,XXII) e lei de origem constitucional (Art. 48 dos ADTC/CF), é bem possível que tais normas sejam consideradas "imperativas" 132 , de ordem pública internacional $1^{133}$ ou leis de aplicação imediata, ${ }^{134}$ aplicando-se, pois,neste último caso, mesmo antes das normas de DIPr. ao caso. ${ }^{135}$ opinião majoritária da doutrina brasileira de

Em matéria de contratos de consumo,

Veja, por todos, BARBAGALO, p. 25 e BENEVIDES DE CARVALHO, p. 108, o qual afirma categoricamente: "A operação se regerá pelo princípio do pacta sunt servanda. Nesse sentido, ainda que tais cláusulas impliquem violação flagrante às normas do $\mathrm{CDC}$, tal legislação não poderá ser invocada, prevalecendo as obrigações tat como propostas pelo fornecedor estrangeiro e aceitas pelo consumidor."

Veja, por todos, ARAÚJO, Nádia de, Contratos Internacionais - Autonomia da Vontade, Mercopsul e Convenç̃es Internacionais, Ed. Renovar, Rio de Janeiro, 1997, p. 108 e seg.

O Brasil ainda não ratificou a CIDIP do México de 1994 sobre contratos internacionais, que expressamente prevê, em seu Art. 11, que as normas nacionais imperativas (mandatory rules) afastam a eventual autonomia de vontade, conexão principal da CIDIP. Veja sobre a Convenção, ARAÚJO, p. 108 e seg.

${ }^{3}$ A exceção de ordem pública tem um claro fim social e de proteção, não só do sistema do DIPr. , mas também, nos países da família de direito continental-europeu, das políticas públicas ou objetivos de harmonia social interna, BUCHER, Andreas, L'ordre public et le but social de lois en droit international privé, Recueil de Cours, 1993, II, t. 239, Nijhoff, Dordrecht, 1994, p. 60 a 69.

"Na definição clássica de Franceskakis, reproduzida por BUCHER, p. 39, são leis ou regras "don’t l'observation est nécessaire pour la sauvegarde de l'organisation politique, sociale ou économique du pays.”, veja Art. 7, alinea 2 da Convenção de Roma da UE sobre lei aplicável às obrigações contratuais de 1980. Tais normas se aplicam diretamente. Veja sobre o Art. 18 Lei de Dir. Internacional Privado suíça, BUCHER, p. 39. Esta expressão quer incuir a nacional "lois de police et sûreté" e as regras substanciais ("Sachnormen", "Gesetzen von streng positiver, zwingender Natur") com aplicação imediata em casos nacionais ou internacionais ou de "ordre public international", assim MARQUES DOS SANTOS, vol. I António, As Normas de Aplicaşăo Imediaamor Din 1991 Internacional Privado - Esboço de uma Teoria Geral- vol. L, Coleccão de Teses, Ed. Alnedina,Coimbra, 199 p. 11. Veja também SCHWANDER, Ivo, Lois d'application immédiate, Sonderanknupfung, IPR-Sachnormen und andere Ausnahmen von der gewöhnlichen Anknüpfung im internationalen Privatrecht, Schulthess, Zuri-
que, 1975, p. 132-184.

Intressante notar também os artigos 2, 17 e 3 do Código de Defesa do Consumidor asseguram responsabilidade objetiva contra defeitos de produtos e serviços, como se esses fossem produtos manufaturados no pais ou importados, assim como se o fabricante fosse nacional ou estrangeiro, produtor e que nacionalidade tem a internacioanis. 
Especial atenção merece o fato do mandamento de proteção do consumidor, como direito fundamental a obrigar o EstadoLegislador, o Estado-Juiz e o Estado-Executivo a uma ação positiva na tutela destes agentes vulneráveis do mercado brasileiro, estar incluído no inciso XXXII do Art. $5^{\circ}$ da Constituição Federal, artigo que em seu caput assegura estes direitos a brasileiros e a estrangeiros residentes no Brasil. Dai se retira que a nova ordem pública constitucional brasileira inclui necessariamente a "defesa do consumidor." A pergunta é o grau, nível ou standard desta proteção em casos de Direito Internacional Privado. Em outras palavras, se em casos pluriconectados todas as normas do Código Brasileiro de Defesa do Consumidor seria imperativo ou de ordem pública internacional (grau total de aplicação), ou se somente a preocupação de "defesa do consumidor" seria obrigatória, podendo ser alcançada pela aplicação eventual de uma le estrangeira, indicada aplicável pelas normas da LICC/42; ou o nível de defesa do consumidor alcançado pelo $\mathrm{CDC}$, é considerado, face a sua origem constitucional (Art. 48 ADCT), como obrigatório a tutelar os brasileiros e estrangeiros (pessoas físicas) residentes no Brasil, standard mínimo de "defesa do consumidor", que leva à aplicação imediata destas normas tutelares, que,porém, não impedem que outras estrangeiras sejam aplicadas, se asseguram nível superior de defesa ao alcançado pelo CDC. ${ }^{136}$

Dando preferência a última hipótese cabe especificar que as chamadas "leis de aplicação imediata" são leis básicas de segurança do mercado ou sociedade ("sauvegarde de l'organisation politique, sociale ou économique du pays"), leis para nacionais e estrangeiros e para todas as relações privadas, sem necessidade de antes passar pelo método clássico do Direito Internacional Privado, da indicação de uma lei aplicável. Esta própria lei "de aplicação imediata" ou lei de "polícia" tem pretensões de aplicação genérica e extraterritorial sempre, não importando se são leis de direito privado ou público, uma vez que positivam fortes interesses de organização da sociedade nacional. Como a chamada lei de aplicação imediata é direta ou resolve o conflito diretamente, sua aceitação e identificação hierárquica dentro do DIPr. é uma técnica (por sinal cada vez mais usada) de "materialização" das novas regras de conflitos de leis. ${ }^{137}$

Para o nosso exame, interessante notar que as normas do CDC são de ordem pública interna $\left(\right.$ art. $1^{\circ}$ ), que os artigos $2^{\circ} \mathrm{e} 3^{\circ}$ do Código de Defesa do Consumidor denotam sua aplicação a todos consumidores finais, nacionais ou estrangeiros (independente de sua nacionalidade ou domicílio) e fornecedores, nacionais e estrangeiros. Assim, dispõe o CDC, em espírito de inclusão semelhante ao do atual Art. $3^{\circ}$ do Código Civil de 1917, ${ }^{138}$ e com espírito de real proteção do vulnerável, sem mencionar a nacionalidade ou o u domicílio dos agentes

${ }^{136}$ Veja von HOFFMAN, Bernd von, Über den Schutz des Schächeren bei internationalen Schuldvertragen, in
RabelsZ $38(1974)$. RabelsZ 38 (1974), p. 401 e seg.

${ }^{137}$ Segundo Erik Jayme (JAYME, Hague Cours, 1995, p. 44), uma das tendências do direito internacional privado pós-moderno ou atual seria a materialização das regras de conflito de leis e aplicação reiterada da lex fori. Após a chamada "american revolution", movimento doutrinário e jurisprudencial ocorrido nos Estados Unidos na década de 1960, que repensou o método e a idéia de justiça no direito internacional privado, as regras de conflito de leis teriam superado seu automatismo e simples posição instrumental de indicação de uma lei material para resolver "diretamente" o conflito, passando agora a interessar-se pela solução concreta ou direta (material) do caso.

${ }^{138} \mathrm{O}$ Art. $3^{\circ}$ do CCBr. atual dispõe:"A lei não distingue entre nacionais e estrangeiros quanto à aquisição e ao gozo dos direitos civis." Infelizmente este artigo não foi repetido pelo novo Código Civil brasileiro aprovado em
10.01.2002.

Revista da Faculdade de Direito da UFRGS, v. 21, Março/2002 da contratação à distância: “Art. $2^{\circ}$ Consumidor é toda pessoa física ou jurídica que adquire ou utiliza produtos ou serviço como destinatário final. Parágrafo único. Equipara-se a consumidor a coletividade de pessoas, ainda que indetermináveis, que haja intervindo nas relações de consumo." E o Art. 29 complementa: "Para os fins deste Capítulo e do seguinte, equiparam-se aos consumidores todas as pessoas determináveis ou não, expostas às práticas nele previstas."

Também o art. $3^{\circ}$ do Código de Defesa do Consumidor inclui como fornecedor "toda pessoa física ou jurídica, pública ou privada, nacional ou estrangeira, bem como os entes despersonalizados," que desenvolvam "atividade de produção, montagem, criação, construção, transformação, importação, exportação, distribuição ou comercialização de produtos ou prestação de serviço". Mencionados expressamente também no Art. 12 do CDC estão os fabricantes, produtores e construtores estrangeiros e o importador de produtos estrangeiros.

Todos estes artigos bem denotam a "vontade" do Código de Defesa do Consumidor em aplicar-se também a casos de consumo internacional ocorridos no mercado

brasileiro ou com os consumidores que protege. Parece-me, pois, tratar-se de uma lei de aplicação imediata. ${ }^{139}$

Efetivamente, parte da doutrina defende que o Código de Defesa do Consumidor deve se aplicar a todos os contratos do consumidor com contatos suficientes ao Brasil, enquanto uma regra imperativa internacional ou lois d'application immediate ${ }^{140}$ O Código de Defesa do Consumidor deve fornecer padrões mínimos ( e imperativos) à proteção de consumidores-passivos em todos os contratos à distância, contratos negociados no Brasil por nacionais ou estrangeiras ou quando o marketing ou a oferta forem feitos no Brasil, inclusive nos contratos eletrônicos com fornecedores com sede no exterior, ${ }^{141}$ como impõem o Unfair Contract Terms Act de 1977 do Reino Unido, ou a lei alemã de 1976 (Art. 12 e Art. 29a da EGBGB), ${ }^{142}$ ou a lei portuguesa de 1985 (Art. 33). ${ }^{143}$

Assim, se a conclusão do contrato for precedida por um convite ou indução ao negócio dirigido a ele ou genérico por meio da publicidade, ${ }^{144}$ e o consumidor realizou no Brasil todas as medidas necessárias de sua parte para a conclusão do contrato (aceitação válida), a le brasileira possui contatos mais próximos e deve

${ }^{139}$ Examinando as leis alemãs de proteção ao consumidor e o novo Art. 29a da Lei de Introdução ao Código Civil alemão (EGBGB), conclui no mesmo sentido Reic/Nordausen, p. 95 a 99

${ }^{140} \mathrm{Veja}$ meu Artigo CIDIP e REICH/NORDHAUSEN, p. 159 e seg.

${ }^{141}$ Assim também sugere LORENZETTI, Comercio eletrónico , p. 256 para a Argentina.

${ }^{142}$ Winter relembra que também que as normas sobre seguros e proteção dos consumidores são imperativas na Alemanha, WINTER, p. 1461

${ }^{143}$ Como ensina Pierre MAYER, p. 521 estas são leis de aplicação imediata que determinam expressamente seu campo de aplicação, impondo sua palicação a todos os contratos de consumo, se o consumidor tem nestes países a sua residência habitual e realizou todos os atos de conclusão do contrato sem sair do país (Consumidor passivo). Veja como o consumidor passivo no comércio eletrônico é protegido também nos Estados unidos, nas leis de Ohio, Virginia e Wasington e na lei suíça, in KRONKE, Herbert, Applicable Law in Torts and Contracts in Cyberspace, in Internet- Which Court Decides? Which Law Applies, Boele-Woelki, Katharina e Kessedjian, Catherine, Kluwer Law International, 1998, p. 82 e 83.

${ }^{144} \mathrm{~A}$ simples publicidade online, com efeitos no país, já pode violar as normas imperativas do direito do consumidor, como comprova a decisão do Tribunal de Frankfurt (OLG Frankfurt), de 31.05.2001, envolvendo publicidade de farmácia holandesa oferecendo medicamento proibido na Alemana. Veja ZIP 2001, p. 1164 a 1168.

Revista da Faculdade de Direito da UFRGS, v. 21, Março/2002 
se aplicar ao contrato internacional de consumo, de forma a favorecer o contratante mais fraco. Deve ser um risco profissional do fornecedor, qual se utiliza destas tecnologias novas e deste tipo da marketing à distância, o eventual uso das normas imperativas ou de aplicação imediata do país do domicílio ou residência habitual do consumidor, onde a oferta à distância resultou em contratação. ${ }^{145}$ Segundo a doutrina francesa a proteção dos contratantes mais fracos é melho realizada se as normas tutelares nacionais são consideradas "leis de aplicação imediata". ${ }^{146} \mathrm{~A}$ doutrina estrangeira conclui que esta é a prática da maioria dos países do primeiro mundo. ${ }^{147}$ Esta teoria parece ser compartilhada pela jurisprudência do STJ.

Parte da doutrina sobre comércio eletrônico considera esta aplicação direta do Código de Defesa do Consumido demasiadamente extensiva e defende a aplicação das regras tradicionais nacionais de conflitos de lei. ${ }^{148}$ Apoiando a solução da LICC de 1942 e a aplicação da lei do fornecedor (ou por que propõe o contrato -art. $9^{\circ}, \S 2^{\circ} \mathrm{LICC}$, ou porque escolhe a DIPr., ou porque tem a conexão mais estreita ao realizar a prestação característica-lei do lugar da execução), consideram estes autores que é risco do consumidor fazer uma transação à distância internacional e a aplicação da lei mais favorável ao fornecedor é uma conseqüência aceitável. ${ }^{149}$

Já a doutrina consumerista geralmente desconhece a teoria das leis de aplicação imediata em DIPr. e defende -de lege ferenda- $a$ aplicação da lei local do domicílio ou a residência do consumidor, se a oferta for feita no Brasil ${ }^{150}$ ou que as normas do CDC são de ordem pública internacional. ${ }^{151}$ Dada máxima vênia a este esforço louvável de proteção dos contratantes mais fracos, o uso excessivo da sua lei no contrato -autonomia da vontade em

${ }^{145}$ Assim as conclusões do $5^{\circ}$ Congresso Brasileiro de Direito do Consumidor, in Revista Direito do Consumidor vol. 33, p. 265: : "11. As normas do CDC, como expressamente consignado em seu artigo $1^{\circ}$, são de "ordem pública e de interesse social", entre a ordem pública local e a ordem pública estrangeira o juiz deve preferir ordem pública de seu país; as disposições do CDC, por serem normas de ordem pública, não podem deixar de ser aplicadas às relaçóes de consumo que envolvem consumidores residentes no território nacional, ressalvada a aplicação cumulativa da legislação estrangeira mais favorável. (aprovada por unanimidade)". Veja também FERNANDES, Antônio Joaquim, "Responsabilidade do provedor de Internet", in Revista Direito do Consumidor, vol. 26, p.49.

${ }^{146}$ Assim conclui o grande professor de DIPr. francês, Pierre MAYER, p. 531.

${ }^{147}$ Veja, por todos, KRONKE, p. 82, Stoll, p. 473 e seg. e JUNKER, RIW 1999, p. 815. Assim conclui até mesmo o advogado da Microsoft,. em seu Curso de Haia de 2001, SMITH, p. 330, mesmo protestando contra esta prática e pedindo que a Internet seja regulada de forma mínima. Segundo ele: "An online business person's potential nightmare is responding to an order from a foreign customer, only to find oneself accused of violating foretg la...The risk, of course, exists for any company engaged in inerion

${ }^{148} \mathrm{Cf}$. GRECO, 2000, p. 50

${ }^{149} \mathrm{VejaCf}$. GRECO, 2000, p. 50 e BENEVIDES DE CARVALHO, p. 108

${ }^{150}$ Assim LUCON, Paulo Henrique dos Santos, "Competência no comércio e no ato ilícito eletrônico, in DeLucca e Simão, Direito e Internet-Aspectos Jurídicos Relevantes, São Paulo, Edipro, 2000, p. 351 a 370, p. 354-355.

${ }^{151}$ Assim MARTINS CASTRO, Luiz Fernando, O comércio eletrônico e a Defesa do Consumidor no Direito Brasileiro e no Mercosul, in Internet e Direito- Reflexões doutrinárias, Roberto Rodrigues da SILVA Júnio (Coord.), Ed. Lumen Juris, Rio de Janeiro, 2001, p. 138 e 139, veja também conclusão independente do Congresso de Minas 2000, in RDC 35, p.265.

Revista da Faculdade de Direito da UFRGS, v. 21, Março/2002 ordre public international, ${ }^{152}$ se bem que comum nos países Latino-Americanos (veja-se o Código de Bustamante), traz sérias perturbações ao sistema de DIPr. ${ }^{153}$ O resultado seria de que qualquer lei estrangeira indicada aplicável em qualquer questão de consumo passaria a ofender a nossa ordem pública internacional (Art. 17 LICC), simplesmente por não ser igual a lei brasileira, descaracterizando a ordem pública em DIPr. como uma exceção ao sistema, em que se aplica a lex fori (no caso, a lei brasileira) face ao resultado concreto da aplicação da lei estrangeira, o qual, este sim, ofenderia os pilares e valores básicos de nosso ordenamento jurídico. Esta solução radical e genérica só pode ser aceita se considerarmos que as regras materiais do $C D C$ seriam (algumas) de ordem pública internacional por se caracterizarem ou positivarem direitos fundamentais (Art. $4^{\circ}$ do Código de Bustamante). Sendo assim, o melhor é atualizar as nossas regras de DIPr., ou aceitando as sugestões aqui realizadas ou-pelo menos reinterpretando-as para incluir as normas do

CDC como leis de aplicação imediata, como tem feito a jurisprudência.

\section{Exame da jurisprudência e a} doutrina consumerista

Efetivamente, a jurisprudência brasileira tem aplicando o CDC a casos pluriconectados, antes do recurso à Lei de Introdução, como lei de aplicação imediata. Vejamos.

Nos casos de importação, realizados com a intermediação de empresas e filias no Brasil, a jurisprudência aplica o CDC, sem sequer mencionar a LICC (a qual também indicaria aplicável a lei brasileira). Assim,o 1.TACiv. de São Paulo julgou um caso sobre a aquisição de grama importada para um jardim particular e aplicou o Código de Defesa do Consumidor, condenando o fornecedor. ${ }^{154} \mathrm{Da}$ mesma forma o TJ do Paraná julgou um caso sobre garantias de um carro importado, utilizando-se do Código de Defesa do Consumidor. ${ }^{155}$ Neste caso, o qual envolve

Esta é uma teoria francesa do início do século XX: "les lois d'intérêt général qui s'imposent toujours à son observation sur le territoire où elles ont été édictées. Nous comprendrons ces dernières sous le nom de lois d'ordre public international." Assim André WEISS apud ANDEREGG, Kirsten, Ausländische Eingriffsnormen im internationalen Vertragsrecht, Ed. Mohr, Tübingen, 1989, p. 9. Sobre Codigo de Bustamenate veja SAMTLEBEN, Jürgen, Derecho Internacional Privado en America Latina- Teoría y Práctica del Código Bustamante, Ed. Depalma, vol. I, Buenos Aires, 1963, p. 270

${ }^{153}$ Assim também conclui, Pierre MAYER, p. 531

${ }^{154}$ Assm a decisão do Tribunal de Alçada de São Paulo (1.TACivSP), 09.02.1999, Des. Jô Tatsumi, Ap. 812.8487. "DECADÊNCIA-INOCORRÊNCIA- ACCÃO INDENIZATÓRIA- SEMENTES DE GRAMÍNEAS- Entrega de produto diverso À luz do Códioo de Defesa do Consumidor, a semente destinada à germinação não pode ser equiparada ao produto não durável, pois não se consome ou se destrói pelo simples lançamento ao solo, se figurando, assim espécie sui generis de peculiaridades correlatas com produtos duráveis, uma vez que o fim a que figurando, assim, espécie su gen se desto que impedem o reconhecimento da decadência do direito à indenização pela entrega das sementes de tramínas de variedade diversa da comprada, pois transcendem à conceituação binária do art. 26 da Lei $8.07 /$ 90.", in Revista dos Tribunais 767 (1999), p. 260. ${ }^{155}$ Assim a decisão do Tribunal de Justiça do Paraná, Ap. Civ. 40.534-4, 23.08.1995, Des. Troiano Netto, envolvendo defeitos de um Lada importado (carro russo), porém aplicando o limite de 30 dias para reparar (Art. 18 Código do Consumidor) com flexibilidade. "Ao conceder prazo para ser corrigido dazo somente no fim do

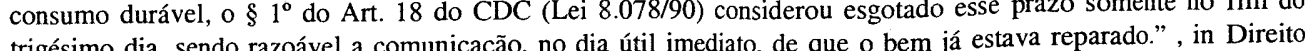
trigésimo dia, sendo razoável a comunicaçăo, no dia util imediato, de que o bem ja estavare a um caso nacional, do Consumidor-Juris Direito do Consumidor-Jurisprudência Brasileira, vol. 181, Ed. Juruá, 1998, p. 135

Direito do Consumidor-Jurisprudência Brasileira, vol. 181, Ed. Junua, 1958, p. 135

Revista da Faculdade de Direito da UFRGS, v. 21, Março/2002 
vícios de um Lada importado (de fabricante russo), o limite de tempo de 30 dias para o conserto, de acordo com art. 18 do Código de Defesa do Consumidor, foi aplicado com flexibilidade, tendo em vista as dificuldades normais à importação. ${ }^{156}$ Já o TJ do Rio de Janeiro ${ }_{157}$ considerou que 55 é dias demasiado longo para importar um motor (para substituir outro com defeito) dos EUA a um carro brasileiro da GM, pois conforme dita o art. 32 do Código de Defesa do Consumidor: "Os fabricantes e importadores deverão assegurar a oferta de componentes e peças de reposição enquanto não cessar a fabricação ou importação do produto. Parágrafo único. Cessadas a produção ou importação, a oferta deverá ser mantida por período razoável de tempo, na forma da lei." Neste caso o fabricante foi responsabilizado a pagar o aluguel de um automóvel para o consumidor pelo período de 55 dias. Nestes casos, que envolvem consumidores-passivos no Brasil $e$ fornecedores estrangeiros com a empresa matriz, filial ou subsidiária, ou empresas de importação no Brasil, podem os consumidores escolher se acionam o varejista, o comerciante, o importador, o fabricante, isolada ou conjuntamente, conforme os artigos 18 e 100 do Código de Defesa do Consumidor.

Especificamente, sobre contratação à distância na jurisprudência brasileira, o n úmero de casos ainda é pouco, mas mencione-se o rumoroso caso de contratação de serviços internacionais de lazer aos consumidores, conhecido como "caso do telesexo internacional". Neste caso, fornecedores de serviços dos países nórdicos estavam oferecendo "serviços sexuais", via telefone, no serviços telefônicos nacional (a Telebrás). Os custos deste serviço internacional eram pagos através das contas normais do telefone, fazendo com que, desse modo, $1^{\circ}$ TACiv. de São Paulo decidisse que o fornecedor responsável era empresa brasileira, aplicando o Código de Defesa do Consumidor a estes contratos internacionais de consumo. ${ }^{158}$

Uma questão muito polêmica, onde bem se notou a imperatividade e importância da normas de defesa do consumidor no Brasil, fo a referente ao leasing massificado "em dólares" de automóveis nacionais. ${ }^{159}$ No caso, ambas as partes contratantes tinham domicílio e sede mercado brasileiro através de um fornecedor de

${ }^{156}$ Compare a um caso de venda de um carro nacional, onde os mesmos 30 dias (limite do tempo) foram permitidos, todavia o fornecedor (Volkswagen do Brasil S.A) teve de pagar os danos pela aflição emocional, pois o tempo de espera foi demasiado longo e utilizado de forma negligente, decisão do Tribunal de Justiça de Minas Gerais: "INDENIZAÇÃO- DANO MORAL. COMPRA E VENDA - VEÍ́CULO- DEFEITO DE FABRIMIDOR. O consumidor que adquire veículo zero quilômetro não pode pedir a restituição das parcelas pagas MIDOR. O consumidor que adquire veículo zero quilômetro não pode pedir a restituição das parcelas pagas quando os defeitos ocorridos com o automóvel são sanados no prazo de 30 dias previsto em lei. A reparação
título de danos morais é devida pelo aborrecimento, desconforto e angústia sofridos pelo consumidor, aliados à título de danos morais é devida pelo aborrecimento, desconforto e angústia sofridos pelo consumidor, aliados
afronta, por parte da empresa, ao princípio da confiança."(Ap.C., 297.423-2, Desa. Maria Elza, 249.03.2000, TJMG)

${ }^{157}$ Tribunal de Justiça do Estado do Rio de Janeiro, j 17.03.98, Des. Samy Glanz, ApC. 865/97, in RT 754 (1998), p. 399. ${ }^{158}$ Assim a decisão do 1 ${ }^{\circ}$ TACivSP, 24.11.98, Juiz Antonio de Pádua Ferraz: "PRESTAÇÃo DE SERVIÇOSTELESEXO DDI- Empresas estrangeiras fornecedoras do serviço se submetem à lei brasileira, notadamente o Código de Defesa do Consumidor, que veda a prestação de serviço sem a solicitação prévia - Inaplicabilidade do art. 129 do Código Civil- Inteligência dos art. 1 e 39 III e parágrafo único da Lei 8.078/90" in RT 765, p. 231 234. Veja também sobre Telefonia decisões do TJ de São Paulo, in Revista Direito do Consumidor, vol. 34, p. 311 e in Revista Direito do Consumidor, vol. 35, p. 347.

${ }^{159}$ Veja decisões do Tribunal de Justiça do Rio de Janeiro, in Revista Direito do Consumidor, vol. 34 (2000), p. 281 e do Tribunal de Justiça de Minas Gerais, in Revista Direito do Consumidor, vol. 35 (2000), p. 329. no Brasil, a contratação era regida pela lei brasileira, o veículo era nacional, não se tratava de contratação internacional, mas sim de transferência interna de riscos (variação do dólar) da cadeia de produção (que realizou mútuo internacional), para os consumidores (que recebiam o risco, como indexador e base sinalagmática de seus contratos de adesão massificados). ${ }^{160}$ A primeira decisão ${ }^{161}$ aplicou o Código de Defesa do Consumidor a estes contratos de leasing especial, aceitando a tese da imprevisão para os consumidores na época da maxidesvalorização, e revisou a cláusula do leasing que substitui o dólar norte-americano por um indexador nacional da inflação. ${ }^{162}$ Estes contratos foram considerados contratos nacionais e o Código de Defesa do Consumido foi aplicado. ${ }^{163}$ A solução jurisprudencial veio para igualar o tratamento dos consumidores, impedindo a lesão e o abuso na transferência de risco (internacional) profissional ao consumidores do mercado nacional.

O caso de líder em matéria de produtos serviços estrangeiros e o standard mínimo de proteção dos consumidores tem origem no STJ. Trata-se de um caso envolvendo um turist brasileiro (consumidor ativo), que retorna ao mercado brasileiro, neste sentido, pode se usado apenas analogicamente para solucionar os aqui analisados. Nesta decisão de líder, STJ responsabilizou a filial brasileira pela garantia de produto adquirido nos EUA

(distribuído pela matriz no Japão e produzido possivelmente na Indonésia ou China), da marca Panasonic, tudo segundo o Código Brasileiro de Direito do Consumidor, considerado "lei de aplicação imediata".

OREsp. 63.981-SP, cujo relator foi o Min. Sálvio de Figueiredo Teixeira, foi decidido em 4 de maio de 2000, com a seguinte ementa:

"DIREITO DO CONSUMIDOR. FILMADORA. DEFEITO DA MERCADORIA. RESPONSABILIDADE DA EMPRESA NACIONAL DA MESMA MARCA (PANASONIC). ECONOMIA GLOBALIZADA. PROPAGANDA. PROTEÇÃO AO CONSUMIDOR. PECULIARIDADE DA ESPÉCIE. SITUAÇÕES A PONDERAR NOS CASOS CONCRETOS. NULIDADE DO ACÓRDÃO ESTADUAL REJEITADA, PORQUE SUFICIENTEMENTE FUNDAMENTADO. RECURSO CONHECIDO E PROVIDO NO MÉRITO, POR MAIORIA. I- Se a economia globalizada não mais tem fronteiras rígidas e estimula e favorece a livre concorrência, imprescindível que as leis de proteção ao consumidor ganhem maior expressão em sua exegese, na busca do equilíbrio que deve reger as relações jurídicas, dimensionando-se, inclusive, o fator risco, inerente à competitividade do comércio e dos negócios mercantis, sobretudo, quando em escala internacional, em que presentes empresa poderosas, multinacionais, com filiais em vários

${ }^{160}$ Veja meu artigo, Banking in the information society, in Consumer law in the information society, Thomas WILHELMSSON et al. (eds.), Kluwer international, 2000, p. 247-262.

${ }^{161}$ Veja decisão of Tribunal Regional Federal $3^{\mathrm{a}}$ Região, Des. Newton de Lucca, 31.05.2000, AI 1999.03.00.0047289: AGRAVO DE INSTRUMENTO AČ̃̃O CIVIL PÚBLICA. DIREITO DO CONSUMIDOR. OAB. LEGITIMIDADE ATIVA AD CAUSAM. JUSTIÇA FEDERAL. COMPETÊNCIA. CONTRATOS DE ARRENDAMENTO MERCANTIL. INDEXAĈ̃O EM DOLAR NORTE-AMERICANO. REVISÃO CONTRATUAL LIMINAR. REQUISITOS. PRESENÇA. O Código de Defesa do Consumidor garante a possibilidade de revisão de cláusula contratual que, por fato externo superveniente, venha a se tornar excessivamente onerosa." Veja with the same opinion, Decisão do Tribunal de Justiça de Rio de Janeiro, in RT 775 (2000), p. 355-357.

${ }^{162}$ Assim o caso Proc. 1999.61.00.004437-1, $1^{\text {a }}$ Vara Cível da Justiça Federal-Sao Paulo, Federal Juiz Dr. José ${ }^{162}$ Assim o caso Proc. 1999.61.00.004437-1, $1^{2}$ Vara Cível da Justiça Federal-Sao Paulo, Federal Juiz Dr. José
Henrique Prescendo, 12.02.99, caso Ordem dos Advogados do Brasil-Secção São Paulo v. Excel Leasing e Henrique
outros.

${ }^{163}$ Veja leading case STJ, Resp. 82269-RJ, Min. Waldemar Zveiter. 
países, sem falar nas vendas hoje efetuadas pelo processo tecnológico da informática e no forte mercado consumidor que representa o nosso país. II - O mercado consumidor, não há como negar, vê-se hoje 'bombardeado' diuturnamente por intensa e hábil propaganda, a induzir a aquisição de produtos, notadamente os sofisticados de procedência estrangeira, levando em linha de conta diversos fatores, dentre os quais, e com relevo, a respeitabilidade da marca. III - Se empresas nacionais se beneficiam de marcas mundialmente conhecidas, incumbe-lhes responder também pelas deficiências dos produtos que anunciam e comercializam, não sendo razoável destinar-se ao consumidor as conseqüências negativas dos negócios envolvendo objetos defeituosos."164

Como se observa, se em caso envolvendo turista brasileiro, cuja única conexão com o Brasil era o domicílio do consumidor, o CDC foi aplicado, parece-me provável que o STJ deverá considerar o CDC também "lei de aplicação imediata" em Direito Internacional Privado nos demais casos, em especial nos casos aqui analisados, quando o consumidor passivo contratar no comércio eletrônico, aplicando o CDC, antes do Art. $9^{\circ}$ da LICC/42.

A solução do STJ foi a mesma da União Européia, que considera as Diretivas de proteção do consumidor como "imperativas", 165 aplicando-as sempre como standards mínimos de proteção dos consumidores europeus, sempre que a lei

aplicável é de país fora da zona. A conclusão é de que os interesse de proteção do agente mais vulnerável superam os deharmonia das decisões, melhor seria regular o tema em norma especial na Lei de Introdução ao Código Civil, a exemplo dos Artigos 29 e 29a da Lei alemã.

Neste sentido, repita-se a sugestão que fiz de CIDIP, que poderia ser adaptada às necessidades nacionais:

\section{Art. 2 - Proteção contratual geral}

1. Os contratos e as transações envolvendo consumidores, especialmente os contratados à distância, por meios eletrônicos, de telecomunicações ou por telefone, estando o consumidor em seu país de domicílio, serão regidos pela lei deste país ou pela lei mais favorável ao consumidor, escolhida entre as partes, se lei do lugar da celebração do contrato, le do lugar da execução do contrato, da prestação característica ou lei do domicílio ou sede do fornecedor de produtos e serviços.

2. Aos contratos celebrados pelo consumidor estando fora de seu país de domicílio será aplicada a lei escolhida pelas partes, dentre a lei do lugar de celebração do contrato, a lei do lugar da execução e lei do domicílio do consumidor.

${ }^{164} \mathrm{DJ} 20.11 .2000$, na íntegra, em sua primeira versão, in RDC 35 , p. 270 e seg.

${ }^{165}$ Assim, como conclusão geral, BRÖCKER, Marion, Verbraucherschutz im Europäischen Kollisionsrecht, Peter Lang, Frankfurt am Main, 1998, p. 138 e JUNKER, IPRAX 1998, p. 74..Também JAYME, IPRAX 1999, p. 412. Assim as Diretivas impõem, por exemplo, a Diretiva 1999/44/CE sobre garantias: "Art. 7. (2) Os Estado membros tomarão as medidas necessarias para que o consumidor näo perca a proteção assegurada por esta Diretiva, quando o direito de um Estado terceiro e escolhido para regular o contrato, desde que o contrato possua um vínculo estreito com o território de um Estado Parte (da E.U.)" in RDC 38/313.

Revista da Faculdade de Direito da UFRGS, v. 21, Março/2002

\section{Art. 3 Normas imperativas}

1. Não obstante o previsto nos artigos anteriores, aplicar-se-á necessariamente as normas do país do foro que tenham caráter imperativo, na proteção do consumidor.

2. Tendo sido a contratação precedida de qualquer atividade negocial, de marketing, do fornecedor ou de seus representantes, em especial envio de publicidade, correspon-dências, e-mails, prêmios, convites, manutenção de filial ou representantes e demais atividades voltadas para o fornecimento de produtos e serviços e atração de clientela no país de domicílio do consumidor, aplicar-se-á necessariamente as normas imperativas deste país, na proteção do consumidor, cumula-tivamente àquelas do foro e à lei aplicável ao contrato ou relação de consumo. 